Florida International University FIU Digital Commons

FIU Electronic Theses and Dissertations

University Graduate School

$7-1-1986$

\title{
Dissidence within the Soviet Bloc : the case of Romania
}

Emil Craciun

Florida International University

DOI: $10.25148 /$ etd.FI14061534

Follow this and additional works at: https://digitalcommons.fiu.edu/etd

Part of the Soviet and Post-Soviet Studies Commons

\section{Recommended Citation}

Craciun, Emil, "Dissidence within the Soviet Bloc : the case of Romania" (1986). FIU Electronic Theses and Dissertations. 2662. https://digitalcommons.fiu.edu/etd/2662

This work is brought to you for free and open access by the University Graduate School at FIU Digital Commons. It has been accepted for inclusion in FIU Electronic Theses and Dissertations by an authorized administrator of FIU Digital Commons. For more information, please contact dcc@fiu.edu. 


\section{DISSIDENCE WITHIN THE SOVIET BLOC: \\ THE CASE OF ROMANIA}

by

Emil Craciun
A thesis submitted in partial fulfillment of the requirements for the degree of
MASTER OF ARTS
in

INTERNATIONAL STUDIES

FLORIDA INTERNATIONAL UNIVERSITY

Thesis Committee:

Professor Farrokh Jhabvala, Chairperson

Professor Ralph S. Clem

Professor Brian Nelson 


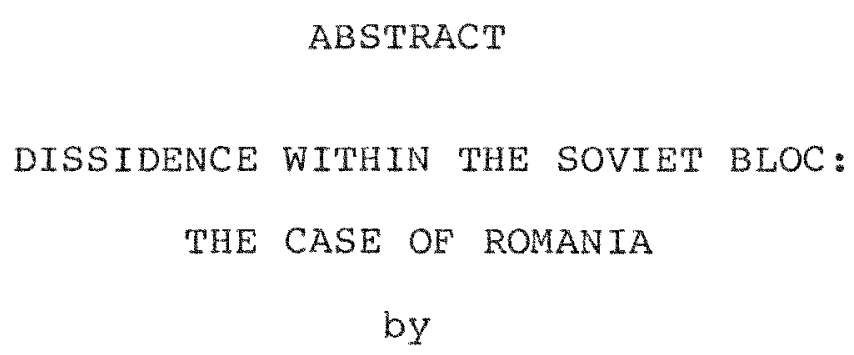

Emil Craciun

This study examines why Romania's dissidence within the Soviet bloc has not provoked a military response from the Soviet Union during the 1965-1985 period. The hypothesis assumed is that soviet tolerance is granted to Romania in exchange for its internal orthodoxy.

Based on English and Romanian sources of information and on the author's experience having lived in Romania, the following factors are analyzed: Party internal control, its organization, leadership and ideology.

The study concludes that Romania's internal

orthodoxy, closely resembling Soviet society, has

neutralized the country's dissident foreign policy saving it from a soviet military intervention.

Professor Farrokh Jhabvala, Chairperson

Professor Ralph S. Clem

Professor Brian Nelson 
To Professors:

Farrokh Jhabvala

Ralph S. Clem

Brian Nelson

This thesis, having been approved in respect to form and mechanical execution, is referred to you for judgment upon its substantial merit.

James A. Mau, Dean

College of Arts and Sciences

The thesis of Emil Craciu s approved.

Professor Farrokh Jhabvala

Professor Ralph S. Clem

Professor Brian Nelson

Date of Examination: July 1, 1986 


\section{DISSIDENCE WITHIN THE SOVIET BLOC: \\ THE CASE OF ROMANIA}

by

Emil Craciun

A thesis submitted in partial fulfillment of the
requirements for the degree of

MASTER OF ARTS

in

INTERNATIONAL STUDIES

FLORIDA INTERNATIONAL UNIVERSITY

1986 
TABLE OF CONTENTS

INTRODUCTION

PART I. 4.

Chapter One. Historical Background

Chapter Two. Review of Literature

9.

PART II. PARTY CONTROL IN ROMANIA

39.

Chapter Three. Internal Control

42.

Chapter Four. The Party

63.

Chapter Five. Party Leadership

81.

Chapter Six. Party Ideology

90.

PART III. CONCLUSIONS

102.

Footnotes

106.

Bibliography

118.

vita

123. 
INTRODUCTION

Since the mid-1960s Romania has radically changed its foreign policy and has pursued a new course of international conduct characterized by analysts as "dissident" or "deviant." 1 This shift came as a surprise to foreign political observers because the country was at the time considered to be among the most reliable satellites of the Soviet Union. 2

The new direction of Romania's foreign policy was clearly expressed in the celebrated "Statement on the Stand of the Romanian Workers' Party Concerning the Problems of International Communist and Working Class Movement" issued by the Romanian Communist Party (RCP), in April 1964. 3 This statement which came to be known as Romania's "Declaration of Independence," proclaimed the country's opposition to Soviet domination and its firm desire for an independent status in the communist world. The declaration, expressed in a defiant, nationalistic tone, became the ideological base for Romanian "national communism," a force skillfully exploited by the RCP, on the one hand for rejecting soviet supremacy and, on the other, for consolidating the RCP's domestic monopoly of power.

This study endeavors to examine why Romania's dissidence within the Soviet bloc has not provoked a 
military response by the Soviet Union. The hypothesis set out here is that Romania's autonomous foreign policy was tolerated by the Soviet Union because the RCP preserved an orthodox communist ideology internally along the lines of the Soviet model and retained exclusive control over domestic political power. This total control led in time to an increasingly oppressive domestic policy which became the Party's lever for satisfying Soviet concerns regarding the security of communist ideology in the face of Romania's questionable international behavior.

As is commonly known, any inquiries into the intimate relations of Soviet-bloc states have to deal with the scarcity, and often the lack of accuracy, of data. This fact can easily mislead the research process by keeping it away from the hidden facets of the inner life of Eastern Europe altered by the Soviet shadow. Romania's case is not an exception. Its bold pursuit of its "own road to socialism" was connected with a multitude of factors, each of them having varying weight and significance. 5 The analysis of this phenomenon in its entire complexity is far beyond the limits of the present study. This study focuses instead on an analysis of the role of the RCP in Romania's dissidence during the period, 1965-1985.

The study comprises three parts. The first part presents Romania's historical background and a review of literature regarding its position in the East European 
context. The second part examines the internal consolidation of power by the RCP and its value in enabling Romania to expand the limits of autonomy. The last part presents conclusions of Romania's dissidence based on published opinions of others and on the personal thoughts of the author. 
PART I

ROMANIA IN THE EAST EUROPEAN CONTEXT

CHAPTER ONE

\section{HISTORICAL BACKGROUND}

Located in the Balkan region that for so many centuries has been a battlefield of rival interests, Romania has experienced a tortuous history of conquest and foreign domination. The Romanians' odyssey was not a story of building up a state according to their desire, but that of a permanent fight against those who tried to enforce upon them their will. Confronted so many times with so many different enemies, Romanians learned very early to preserve their national existence in different ways. In order to survive they bent under the invaders' forces, obeyed their rules but watched them closely, yielded and compromised to gain time for achieving their goals. To employ these tactics successfully, Romanian rulers of earlier times were compelled to master an acrobatic diplomacy of tightrope maneuvers--traits which have been inherited through time and are very much alive today.

At the end of World War II, when the Soviet bloc was 
formed, Romania did not have any choice other than to be a part of this bloc. Its future was determined in october 1944, by a decision that concluded a private conversation in the Kremlin between Stalin and Churchill that established the delimitation of spheres of influence in Europe.

Even before World War II was over the country was occupied by the Red Army and the Soviets had started to exercise control over it. After the Paris Treaty (1947), where the legitimacy of Romania's pro-communist government was recognized, the country entered a phase of total subordination to the Soviet Union. Following the abolition of the monarchy (December, 1947) Romania signed a twenty-year Friendship Treaty with the Soviet Union. During that time the Soviets imposed upon the country a demand of heavy payments for war damages caused by the Romanian army in the first years of the war when it fought against the Soviet Union. They forced the government to support the cost of Soviet troops stationed in Romania, demanded the rejection of the Marshall Plan intended to help the country's economy, and isolated Romania from the West. As a Soviet satellite the country was deterred by externally imposed orders and limitations from using its natural resources for its own development and was relegated to the position of being a main supplier of food and raw materials for the reconstruction of the soviet economy. 2 This oppressive economic pattern proved to have a strong and 
lasting effect upon Romania's later development; during the 1965-1975 decade Romania continued to be among the least developed countries in Eastern Europe.

It was this feeling of anger against the tight economic grip of the Soviet Union and a deep frustration arising from discrimination among other satellites, that paved the road of future changes. The long march for independence started slowly after Stalin's death in 1953 and continued with increasing intensity thereafter, especially following the withdrawal of Soviet troops from Romanian territory in 1958.

Faced by adverse geographical conditions $(800$ miles of common borders with the Soviet Union), the country's struggle for emancipation has reflected its traditional style by combining defensive tactics with long-term offensive strategy leavened by a proper timing of action. Perfectly aware of its incapacity to confront the soviet Union directly, the RCP prepared the ground for its defiance in two ways: first, it entered the international arena and exploited some controversial ideological issues as an umbrella for launching its effort of independence from the Soviet Union. Second, it organized national support for its position within the country by appealing to patriotic sentiments and anti-Soviet feelings among the population. The effect of this policy in the last two decades radically changed the character of Romania's external relations, 
ensured a high degree of exposure in the international arena, and alleviated to some extent the shadow of soviet domination.

The following is a summary presentation of Romania's international behavior that reflects its deviation from the Soviet line over the last twenty years:

1. The RCP refused to participate in any conference of communist parties intended to discuss, criticize, condemn or pass judgment upon the political line or conduct of any national party.

2. Romania refused to sever its diplomatic relations with Israel after the Arab-Israel war of 1967.

3. Unlike other countries from the Warsaw Pact, Romania established diplomatic relations with West Germany in 1967. 4. Romania refused to participate in the military invasion of Czechoslovakia in 1968, and vehemently condemned the attack.

5. Romania joined the International Monetary Fund and International Bank for Reconstruction and Development in 1972.

6. Romania was the first memeber of the Council for Mutual Economic Assistance (CMEA) to obtain generalized trade preferences from the European Economic Community (EEC) in 1973, and signed a trade agreement with the EEC in 1976. 7. Romania received from the United States most favored nation trading status in 1975, and remains the only East 
European country with trade-promotion offices operating in the United States.

8. Romania was admitted to the nonaligned bloc of states in 1976.

9. Romania proposed and promoted the idea of reducing the military forces in Europe, including those of both NATO and the Warsaw Pact.

10. Romania refused to permit military maneuvers of the Warsaw Pact on Romanian soil.

11. Romania decided upon a unilateral reduction in military spending in 1978 and 1980, in contradiction with Warsaw Pact goals.

12. Romania expressed dissatisfaction with Soviet intervention in Afghanistan and did not participate in the United Nations General Assembly vote on the issue in 1980. 13. Romania ignored the socialist bloc boycott and sent a Romanian sporting team to the Summer Olympic Games in Los Angeles in 1984.

There are more examples during these years that can confirm this course of deviation from the Soviet line in Romania's foreign policy. However, these deviations were not unlimited. Since a Soviet military intervention was avoided, it is reasonable to suppose that during this time Romania also learned to know and live within the limits of its autonomy. 
CHAPTER TWO

\section{REVIEW OF LITERATURE}

For almost four decades Eastern Europe has been dominated by the Soviet Union. During that period of time substantial changes occurred in Soviet-East European relations, between East European countries themselves, and bewteen Eastern Europe and the outside world. How these changes have affected Soviet hegemony in Eastern Europe and, implicitly, Romania's new course will be presented in this chapter in the view of different authors. Since their opinions are related to many aspects of the problem and cover different periods of time, for the purpose of this study these views have been synthesized in three categories: the first category (a) includes opinions about Eastern Europe in general with references to Romania's case; the second category (b) presents opinions about Romania's economy, political structure, or its relations with the Soviet Union; and the third category (c) concerns views about Romania's independence $v$ is $-a-v$ is soviet tolerance of Romanian policies.

a. Calling the area "The forgotten region," Charles Gati deplores the fact that the United States is no longer committed to defending the cause of Eastern Europe as had been stated in the past by John Foster Dulles and President 
John F. Kennedy. ${ }^{1}$ Yet, Gati said, in spite of Soviet domination and little Western support, Eastern Europe has remained one of the most pro-Western regions in the world in which recalcitrant regimes like those in Romania and Yugoslavia struggle alone for their independence. "We have rightly abandoned our provocative forward strategy toward Eastern Europe, but have wrongly adopted a policy of deliberate indifference." 2

Analyzing Eastern Europe after four decades of existence the same author, in another article, emphasizes the overwhelming Soviet influence in the area. Gati characterizes the struggle of several East European regimes as an attempt to achieve more "elbow room" rather than a real independence. The subtle attempt of these regimes "to move toward the West without appearing to move away from the East, thus avoiding any soviet provocation, confirms in Gati's view "the most fundamental political fact of life in the region: continued dependence on soviet power for survival." ${ }^{3}$

Referring to Romania, Gati characterizes it as "the Soviet bloc's leading maverick," "that continues to irritate the Soviets with its foreign initiatives, but remains internally in a deep economic crisis. The effect of this situation, he said, is that the country's long stand against the Soviet Union "lost much of the attraction it might have once from the other East European leadership." 5 However, he continues, for the Soviet Union itself the situation of the 
region raises many questions as well; the main Soviet dilemma is to choose between the alternatives of a "bloc cohesion enforced by Soviet military power and economic subsidies or a modicum of East European stability made possible by Soviet tolerance of 'goulash communism," 'national communism,' or some combination of the two." Although Soviet leaders have tried in recent times to follow a middle course between bloc cohesion and political stability, creating thereby a new type of Soviet-East European relationship, "diversity is not independence and tolerance is not liberty, "according to Gati.

Referring to the same area, Roger E. Kanet notes that, "since Stalin's death substantial changes in the Soviet-East European relationship have occurred, although the basic Soviet goal of control has remained constant." Asserting that this control has, over time, become more subtle and sophisticated as the Soviet Union has tried "to integrate the region... more fully into the Soviet system," Kanet recognizes that the Soviet threat of using military force in the area "still looms as a distinct possibility." Sharing Charles Gati's view that for Western scholarship the area represents a "forgotten region," he notes that "one gets the impression that some of the recent... analyses of Eastern European politics were motivated far more by the availability of certain types of data rather than by the desire to explain significant 
11

political processes." Referring to Romania, he considers that "although numerous articles have appeared on Romania's autonomy with respect to the Soviet Union, not until recently have more general monographic treatments of Romanian foreign policy been published." ${ }^{12}$ Emphasizing that in order to understand the foreign policies of East European countries one should look closely upon their internal policies, he recognizes that "far too little research has been conducted to date on the relationship between domestic and foreign policy in the European communist states." 13 Therefore, Kanet concludes, more research of this type is needed in order to provide new data and comparative terms, which will contribute to a better understanding of this "underdeveloped area in political science." 14

Focusing his examination upon the same problem, Ladis K. D. Kristof expresses his view that each East European country represents an entity that should be thoroughly studied on an individual basis before any generalization is attempted. Unless basic knowledge of these states is gained, any integrated scheme in the area "is not a reflection of political realities." 15 Mentioning that in the Western view Eastern Europe was only an appendix to Soviet studies, a fact which revealed very little about the political individualities of these states, Kristof states the case of Romania as an example whose political science "is virtually still in diapers." 16 
Consequently, he concludes that it would be inappropriate to engage in comparative studies of East European countries "before knowing something about the colors and basic properties of the stones from which the mosaic is to be assembled." 17

The same idea is supported by Vernon V. Aspaturian, who notes that "for many years the area was homogenized into an amorphous conglomerate collectively referred to as 'Eastern Europe." 18 Acknowledging the difficulties of political comparative studies in the region, he affirms that "not enough basic research has been done on individual countries to enable a great synthesizer to do the job." 19 Referring to national communism as an expression of independence from Soviet control, Gordon Skilling affirms that in Romania the issue was used to maintain domestically methods and forms of Stalinism, including the cult of personality. In his view national communism will continue to remain a major feature in Eastern Europe's policy of resistance against Soviet domination. While Soviet hostility to national communism has not diminished, and the Soviet Union remains ready to respond with force if necessary, the author acknowledges that "there is very little that the West can do to affect the future of Eastern Europe in any decisive way."

Writing about Romania's position within the Soviet bloc, Andrzej Korbonski emphasizes that starting in the 
early 1960 s Romania opposed Soviet pressure on economic integration and labor specialization within the Council for Mutual Economic Assistance, and shifted its external policy to the West and the Third World in order further to trade and obtain credits for its ambitious plan of multilateral development. This external trade orientation, in conjuction with the country's own resources, has led to a lesser degree of dependence on the Soviet union from an economic point of 21

view. However, Korbonski argues that in the international arena, Romania's role was detrimental to Soviet interests: "Romania's behavior in the Third World, and especially in Africa was clearly in conflict with that of Moscow... The same was true for Romania's activities at the various international forums."

Referring to the ideological relationship with the Soviet Union, the author affirms that while under Gheorghiu-Dej the country was a docile Soviet satellite, Ceausescu's leadership since 1965 has drastically changed this situation. If Romania's foreign policy in the last fifteen years "could hardly have pleased the Kremlin," internally the regime's performance "has given Moscow relatively little cause for complaint. It remains the most tightly controlled polity in East Europe."

Assuming that Romania has firmly decided to defend its sovereignty in the face of a soviet military intervention, Korbonski emphasizes that following the soviet 
intervention in Afghanistan "the odds against the use of violence in East Europe obviously have dropped rather sharply." ${ }^{24}$ However, he concludes that it seems that Moscow has learned some lessons from the many crises and events that have occurred in Eastern Europe in recent decades and is trying to do "its best to avoid their repetition." Writing about the changes that have taken place in Eastern European alignment in the last two decades, Peter Summerscale characterizes Romania's foreign policy as remarkably consistent since the early 1960s. The RCP leadership, he says, was able to consolidate its power by identifying itself with national aspirations and by promoting a policy of national economic development. This policy ran counter to the interests of the soviets who attempted to integrate Romania's economy into a more controlled process of development of the socialist bloc as a whole. The supranational planning and the international division of labor that Khrushchev tried to impose in Eastern Europe through CMEA were perceived as threats seeking to maintain Romania's under-development and served "as [a] catalyst for Romania's assertion of independence." 26 The first sign of an autonomous foreign policy, Summerscale writes, was visible in the early 1960 s when Romania tried to mediate the Sino-Soviet dispute. Even though the attempt failed, the Romanian leadership decided to defend its position and preserve its independence within the Socialist bloc. Conceived as a defensive measure, the 
"Declaration of Independence" issued in April 1964, became the theoretical basis for Romania's international policy which has been maintained till the present despite the Soviet Union's efforts to promote the unanimity principle. The declaration emphasized the concepts of national independence, sovereignty, equal rights, non-interference in internal affairs and the principles of socialist internationalism.

Describing Romania's foreign policy as "a series of moves to test the limits of Soviet tolerance in the area of foreign policy and its control of bloc affairs," Summerscale distinguishes certain conditions that have enabled Romania to pursue such a policy. Among them he notes the ties the country has established with the West as well as its relations with China, Yugoslavia, and the non-aligned states. These relations have contributed to lessening Romania's dependence on the Soviet Union and have increased its image of autonomy abroad.

Acknowldeging, that Ceausescu's personality cult and his overriding nationalism are probably unpleasant to the Soviet taste, Summerscale however considers that this fact represents no direct threat to the Socialist camp's cohesion. Subsequently, he therefore advances the idea that the Soviets may come to understand the value of these characteristics in maintaining Romania's internal orthodoxy. "It may indeed well be that the Soviet Union's tolerance of Romanian waywardness is influenced by an understanding of 
the domestic basis on which 'autonomy' rests."29

Questioning whether Romania's pursuit of autonomy is anything more than a means to legitimize the RCP's rule and Ceausescu's own ascendance to power, summerscale observes that Romania's links with the West have produced very Iimited benefits for Romanians who have the lowest living standard in the Soviet bloc. Faced with popular discontent and labor unrest, the regime has resorted to harsh measures against any challenges to its authority, as was demonstrated in the response to Paul Goma's dissident movement or the Jiu Valley miners' strike in 1977. However, the author stresses that "internal Romanian policies have been the object of very limited interest in the Western world and have attracted 30 less attention than Romania's independent foreign policy." This fact has been exploited by the regime by "distracting foreign attention from some of the less happy aspects of internal policy."

b. Robert L. Farlow, characterizes Romania as being "among the most rigid and restrictive of communist states, but...also among the most nationalistic." ${ }^{32}$ The RCP, he says, has "an obsessive pursuit of two objectives: economic development and political autonomy." ${ }^{33}$ The RCP operates according to democratic centralism, but within its structure political power is held by only one person, Nicolae Ceausescu. This power is exercised in the context of nationalistic appeals that emphasize the process of 
"Romanianization." This combination of nationalism and an autonomous foreign policy won popular support in the late 1960s, especially after Romania condemned the Soviet invasion of Czechoslovakia. This support helped the RCP to set its program of rapid industrialization aimed at achieving a multilaterally developed society. The effect of this policy was that "Romania achieved one of the highest industrial growth rates in the world and one of the lowest standards of living in Europe."

During the 1970s, as the problems of development became more complex, Ceausescu intensified his campaign of ideological mobilization in order to create the "new socialist man." If in the beginning the populace participated in the Party's domestic program, during the mid-1970s the dissatisfaction with the RCP's internal policy manifested itself in different forms of opposition beginning with the political dissident movement led by Paul Goma and culminating with the miners' strike in August 1977, in the Jiu valley. The regime, Farlow says, responded with a "carrot and stick" tactic that enabled it to control the situation, making concessions on secondary issues while repressing firmly the challenges to its position. The popular unrest that accompanied social changes during the process of development in Romanian society indicate, in Farlow's interpretation, that "Romanians are less willing to postpone material gratifications for a future socialist 
utopia." 35

Farlow concludes that Romania's foreign policy is a "balancing act between cooperation and deviation," that has permitted "not a permanent alignment, but a permanent bargaining with shifting and overlapping coalitions," while alleviating Soviet suspicions through the repressive 36 domestic policy.

Analyzing the development of Romanian nationalism, George Schopflin underlines that under Ceausescu's leadership Romania has reversed the Leninist line of "national in form and socialist in content," into "socialist in form and national in content." 37 That means, the author contends, that "Lenin is alive and well, and living upside down in Bucharest." Schopflin considers that cultivation of nationalism in Romania has clearly provided the communist regime with a "measure of legitimacy as the defender of the national interests and [has]...offered the leadership a more effective means of mobilization than Marxist ideology alone 39

had proved to be." However, he stresses that nationalist manifestations have been strictly controlled by the Party, which appears to be well aware that traditional anti-Russian feelings among the population could easily transform Romanian nationalism into a dangerous hostility towards the Soviet Union. Mentioning the era of de-Russification auring the early 1960s, Schopflin acknowledges that "it did little or nothing to broaden the limits of liberalization," but 
nonetheless it was an outlet of relief for the anger and frustration which had accumulated during so many years of 40

Soviet oppression.

Asserting that Romanian nationalism has developed not as an adaptation of Marxist-Leninist ideology, but rather vice versa, Schopflin emphasizes that the Party can easily manipulate the people's nationalist feelings in order to deflect their struggle for better living conditions by maintaining an atmosphere of persistent threat to the nation from abroad. This practice, he concludes, "hardly makes Romania a particularly agreeable society domestically." Labeling Romania's present political order as "dynastic socialism", Vladimir Tismaneanu stresses in his article that its nature cannot be explained without taking into consideration the personality of Nicolae Ceausescu, who has "emasculated the institutional role of the RCP." He characterizes Romanian socialism as a "combination of neo-Stalinism at home and neo-Titoism abroad."

Describing Romania's new course as a gradual assertion of national power, Cal Clark notes that until the early 1960s Romania was considered the most docile Soviet satellite. It changed its status through a "partial alignment" that permitted the RCP to exercise an independent foreign policy while remaining within the soviet system. Romania's distinctiveness, Clark says, is that 
Gheorghiu-Dej, who was a loyal stalinist, ultimately defied the Soviet Union and opened the road for Romania's semi-autonomous course." 43

The differences between Romania and the Soviet Union, Clark remarks, began over economic policies, as Romanians objected to Soviet attempts to increase CMEA integration and division of socialist labor. Pursuing the effort of modernization through a rapid process of industrialization against Soviet will, the RCP has established a steady expansion of its external trade with the West. The deviation from the soviet line became more evident during the mid-1960s, when the RCP's "Declaration of Independence" stressed the "right of sovereignty and domestic autonomy and made it clear that these principles should apply to Soviet-Romanian relations."

Under the leadership of Nicolae Ceausescu, Romania's separate foreign policy became more accentuated and helped to increase the RCP's domestic popularity and socialist patriotism, although the internal situation remains "orthodox and conservative." Lespite the fact that relations with the West and the Third World continue to remain active, Clark observes that "Ceausescu apparently realized that he had reached the limits of permissible independence within the framework of bloc membership," and that "Romania's ability to finance trade outside the bloc became increasingly limited." ${ }^{45}$ This fact, clark concludes, 
can lead to a future retrenchment in Romania's external policy.

Analyzing Romania's perspective of development in the 1980s, Stephen Fischer-Galati remarks that the meaning of Romania's economy, foreign policy, independence, or cult of personality continue to be a matter on which scholars differ. It is difficult to find answers to these problems he says, first because Romania has a special position "in the communist and non-communist worlds," and second, because the Party's leadership has pursued a foreign policy that has both conditionea and obscured internal realities. Recognizing Romania's impressive record of industrialization achieved during the last decades, FischerGalati observes that its beneficial effect seems to be undetectable in Romania's economy, which at the beginning of the 1980 s was "in disarray, plagued by shortages of raw materials and hard currency, by enormous trade deficits, inadequate food supplies and inflation." 47 In Fischer-Galati's view, the industrialization process was used by Ceausescu to legitimize and consolidate his power, vis-a- vis internal challenges and Soviet opposition to Romania's independent course. Adopting a "political platform based on nationalism, communism and modernization," Ceausescu's actions were "eminently political" in their character and as such they "have tended to ignore economic 48

realities." This fact would undermine Romania's resistance 
to Soviet internal interference and would determine, in Fischer-Galati's view, a greater economic dependence on the Soviet Union during the present decade.

Examining Romania's external relations, Lawrence $\mathrm{s}$. Graham notes the necessity of interpreting its domestic policy. Asserting that Ceausescu's leadership maintains internally an orthodox Marxist-Leninist line, Graham emphasizes the illusive nature of Romania's autonomy:

There was, in effect, a tacit trade-off between the two countries: in exchange for Romania's willingness to follow what was essentially a Soviet interpretation of Marxist-Leninist orthodoxy and recognition of Soviet supremacy in the Eastern bloc, the Soviet Union would tolerate nationalistic rhetoric designed to create the illusion of national autonomy and would accept the Romanian desire to set its own internal development policy, even to the point of expanding its economic ties with the west.

And Graham continues,

So secure was the Soviet Union's position economically in relation to Romania that multilateralization of trading patterns and economic relationships did little to change the fundamental reality of Romania's economic dependency on the Soviet union.49

This type of autonomy did little to improve the standard of living for Romanians, Graham says, and socialist reality should be separated from the official image of the country promoted through propagandistic means. "Day-to-day Iife is hard; working hours are long: conditions of work are constraining; public transport in the major cities is crowded... food and commodity items are limited and in short 50 supply." 
Within this context, the author distinguishes a number of anomalies that characterize contemporary Romanian society. Among them he notes the opposition between Marxist-Leninist ideology and religion, egalitarianism and privileges, mass mobilization and elitism, collectivism and personalism, the party's ideology and the authoritarian practice of government. Romanian society which has survived despite history's tremendous vicissitudes, appears in Graham's view "difficult to penetrate and understand." And yet, he concludes that "it is the continued cult of close personal relations and contacts and intimacy that gives to this people and this society a vitality and fascination that is worthy of admiration."

Analyzing Romania's situation in 1984, Trond Gilberg begins his article by declaring that "the country is in the midst of a societal crisis that threatens the very fiber of the system." 53 Among the factors responsible for the current economic crisis, Gilberg identifies agriculture plagued by inadequate funding, irrational planning, insufficient numbers of qualified personnel and the lack of technical equipment. These conditions produce a poor agricultural performance, a fact directly manifested in permanent food shortages. Industry, although in better shape, has its own problems arising from waste, lack of spare parts, sloppy work and corruption. The country experiences severe energy crises that result in the "periodic shut-off of electrical power both to industrial 
and to residential quarters." 54 In order to reduce electrical consumption by the citizens, the government has imposed drastic measures, especially during the winter months. This policy is enforced by "roaming vigilante squads whose members arrogantly and threateningly enter private apartments to enforce compliance."

The situation is aggravated by the country's huge foreign debt which "has necessitated periodic renegotiations and payments rescheduling." 56 These external credits that were supposed to boost Romania's economy to a higher level of performance have instead become, in Gilberg's view, a major headache: "The policy of the RCP to reduce dependence on the Soviet Union by orienting its economic life toward the West thus has backfired, since many Western creditors now have serious doubts about the reliability of Romania's economic posture." ${ }^{57}$ By attempting to resolve its shortages of raw materials and fuel with the help of the Arab states, Romania has deepened its crisis since "these sources demand payment in hard currency." 58

In Gilberg's view, the RCP's domestic policy over the past three decades is responsible for all the internal troubles that Romania experiences today. He acknowledges that the country's proximity to the Soviet Union narrows its options in foreign and economic policy, and some natural calamities that have occurred in recent years were beyond the Party's control. However, the main sources of the 
present societal crisis are the RCP's faulty policies started by Gheorghiu-Dej and aggravated under Ceausescu's leadership. Among the effects of these policies Gilberg notes the state of agriculture, which has been almost destroyed in order to force the industrialization process; the extensive industrialization that failed to provide an intensive development for the country; an excessive centralization in planning and control; a permanent and excessive Party interference in technical and managerial matters, and a Byzantine personality cult.

Looking for solutions to these problems, Gilberg thinks that radical changes in Romania are unlikely, since they would imply a "drastic change in the political system," a change which would be "politically fatal to many of those now in power." 59 Moreover, the Soviet leaders, even though displeased "with the self-proclaimed maverick in Bucharest, are not anxious to watch a process of reform that might challenge the very foundation of power in a Warsaw Pact member elite." 60

Recognizing that the Romanian nation which has survived against so many adverse odds may have hidden resources undetectable by a Western observer, Gilberg nevertheless emphasizes, that--faced with an increasing domestic discontent--"Ceausescu must find out at what point the advantages of an autonomist foreign policy are outweighed by its drawbacks." In Gilberg's view, there 
are two factors that threaten Romania's actual system: First, the severity of the current economic crisis: "the larder is very nearly empty." second, the existence of a subculture of young but highly skilled people who are disenchanted with political life in contemporary Romania. Since they have the potential "to make or break the 63

economy," they represent the major threat to Romania's present elite. If the Romanian political order under Ceausescu's leadership fails to incorporate these people into its structure, Gilberg concludes that, "the crisis may indeed become fundamental." 64

c. Writing about Romania's foreign policy, Robert L. Farlow characterizes it as a partial alignment. He defines the term as,

A sub-type of foreign-policy behavior whose general characteristics are, on the one hand, frequent statements by a nation of its desire to remain within a given alignment system and to cooperate with the other members thereof and, on the other hand, only limited cooperation with those members and frequent opposition to the policies upon which they have agreed. 65

Analyzing the question of how Romania was able to avoid Soviet military intervention in regard to its independent course, Farlow distinguishes internal and external factors. Among internal factors he notes the presence of a strong sense of national identity achieved by the RCP's leadership that made the Party "relatively immune to Soviet manipulation;" a strong anti-Russian feeling among the population that helped the party in its policy of defending 
Romania's sovereignty, and the rapid growth of the country's economy that reached a self-sustaining development. Regarding the international circumstances, Farlow notes Romania's willingness to avail itself of all opportunities created by the lessening of tension between the communist and non-communist world due to the soviet Union's policy of promoting the principle of 'peaceful coexistence.' This policy has produced an increased "willingness of the Western powers, especially those in Western Europe, to engage in economic, scientific and cultural exchanges with Communist states." ${ }^{67}$ This fact, Farlow says, has offered to Romania "not only a justification for, but also a concrete means of disengagement from, excessive dependence of Comecon countries." ${ }^{68}$ At the same time, Farlow states that, "the Sino-Soviet dispute, [and] the successful deviation of Yugoslavia and Albania... helped both to divert Soviet attention from Eastern Europe and to limit Soviet leverage over that area."

The conflict between the Soviet union and the East European communist regimes that led to Soviet military interventions are not based on ideological issues but only on the "control over the local communist party." 70 This is the opinion expressed by Christopher D. Jones, who elaborates his position by identifying three tasks that a communist leader, who is seeking autonomy from the Soviet Union, should carry out. First, he needs to purge the party of Muscovite elements and gain firm personal control over 
the Party, army, security organizations, and state and economic bureaucracies. Second, he must secure his position through diplomatic allies in the communist camp, in the West and the Third World. Third, he should create a large domestic popular support for his regime through nationalism and societal development. Although he acknowledges that the cultivation of nationalism can be a "risky enterprise" since it may become an anti-communist revolt, like in Hungary in 1956, he considers that "Dubcek's most critical mistake in 1968 was his failure to take up the cause of Czechoslovak nationalism." 71

Soviet military intervention can be deterred, he argues, by refusing to debate ideological issues with the Soviets, focusing instead on national sovereignty. The reason for doing so is that "a dispute over ideology... is a private conflict between two communist parties; a dispute over the right to national sovereignty makes the conflict a struggle between two nations." ${ }^{72}$ In this way the party leader would gain more popular support for countering Russian imperialism than he could obtain on ideological issues. Accordingly, he would force the Soviets "to make war on his nation in order to obtain control of his party." In Romania's case, Jones says, the party was purged of the Muscovite elements and the leadership, in firm control over the armed forces, presented to the Soviets a 
prospect of war in defense of Romania's sovereignty. Autonomous communists, Jones concludes, are not seeking a complete separation from Moscow, but only "the prerogatives of independence": their foreign policy tends to be one of nonalignment, and their ideology, adjusted to local conditions stresses- as in Ceausescu's case- the value of their view of Marxism to the cause of socialism. Focusing in his article on Romania's independent course, Graeme J. Gill distinguishes two stages of 74

development. In the first, during the 1960s, the author sees three interrelated factors which facilitated Romania's new orientation. First, the Sino-Soviet rift that created for Romania the opportunity for an increased ideological maneuverability by taking a neutral stand in the dispute. Second, the domestic development in the Soviet union which under Khrushchev's leadership started to promote a doctrine of detente with the West, thus, creating for East European states new chances for autonomy and ties with the West. Third, the loosening of Soviet control in Eastern Europe which permitted the RCP to appeal more strongly to national aspirations, to arouse popular nationalism, and to exploit the anti-Russian popular sentiments. These conditions, Gill indicates, have created for Romania "a position more independent of Moscow than that of any other state which remained openly aligned with the Soviet Union." ${ }^{75}$ The second stage of development in Romania's 
independent course has occurred, according to Gill, during the mid-1970s. This stage, the author affirms, was characterized by three main changes. First, Romania's economic position became weaker than it had been during the 1960s, due mainly to the massive repayments of credits to the West. This fact led to compromises with the CMEA and subsequently weakened Romania's autonomous stand. Second, relations with China had cooled significantly as China improved its relations with the United States and entered the United Nations. As a result Romania was deprived of a basic partner in the communist world for counteracting Soviet pressure. It was thus forced to "choose reconciliation with Moscow, reverting to the position of a 'neutral' in Sino-Soviet encounters." The third important change was the Soviet Union's attitude of pursuing a policy of detente with the West. Through a series of compromises that accompanied this process, "Eastern Europe has been reaffirmed as Moscow's backyard," diminishing considerably Romania's chance of Western support in a possible conflict with the Soviet Union. 77

As the Soviets pursued increased Western trade and capital, so did Romania. Furthermore, Soviet opposition to Western ideas and attitudes inside their society was in perfect accordance with Romania's policy, since "in internal affairs Romania remains one of the most orthodox of 78 communist states." Thus, Gill said, the Russians, 
ironically, "appropriated the course which the Romanians had been pursuing." 79 However, he added, for Romania this meant a closer position to the Soviet union and a less independent one.

Asserting that despite all these changes Romania's position remained "largely unchanged," Gill concludes that the country's chances of pursuing its independent course without Soviet punishment are based on two factors that were as important in the 1960 s as they are today. First, the popular support enjoyed by the RCP's leadership; and second, the Soviet perception that Romania does not pose for them a strategic or, "given the internal hard line taken by the Romanians, ideological threat." 80

Analyzing Romania's foreign policy, Robert R. King contends that Romania's uniqueness resides in its avoidance of Soviet military intervention $v i s-a-v$ is its expanded autonomy from the Soviet Union, while remaining at the same time a full member of the Warsaw Pact. ${ }^{81}$ In his view the origin of Romania's autonomy was the disagreement with the Soviet Union regarding economic integration within the CMEA. Since then Romania has expanded its autonomous foreign policy but cautiously has related it constantly to Marxist-Leninist principles and Romanian nationalism. The highest point of Romania's defiance took place, King says, in August 1968, when Ceausescu made his vehement condemnation of the Soviet military invasion of 
Czechoslovakia. In his view, Romania's autonomy from the Soviet Union was achieved not so much through internal factors but by a skillful exploitation of favorable international circumstances. Among them King identifies the Western policies toward the East European states aimed at supporting any move that would disintegrate Soviet domination in the area, the Sino-Soviet conflict that offered the mediation opportunity and permitted the RCP to bargain for Soviet concessions, and the Yugoslav example that presented a new alternative to replace the Soviet relations of subordination with the Soviet Union.

These favorable conditions of the early l960s changed at the end of that decade and became "less helpful to Romania's pursuit and maintenance of an autonomous 82

foreign policy." As detente between the superpowers registered more progress and China entered in the balance of world powers, the significance of Romania's policy in the international arena diminished considerably. King contends that the evolution of security and detente in Europe, represents a crucial factor in the country's future foreign policy:

If detente in Europe progresses as the Romanians hope, then their sphere for autonomous action vis-a-vis the Soviet union will be maintained if not expanded... if Moscow's hope that European security will strengthen its control are fulfilled, Romania will find itself in a very difficult position.83

Analyzing Romanian foreign policy in the 1980s, Ronald $\mathrm{H}$. Linden underscores the linkages between 
international behavior and domestic policy. In his view, Romania's foreign policy needs permanent internal and external economic support and requires at the same time a level of Soviet tolerance. He acknowledges that the Romanian regime has learned from previous Soviet military interventions that it cannot rely on any concrete western help; nor can it count on China's military support in the event of an armed intervention. In this perspective a continuation of the country's deviant foreign policy is based entirely on "the leadership's ability to secure economic and political support where it can and avoid or prevent Soviet military intervention, rather than try to defeat such an intervention once begun."

Regarding the level of Soviet tolerance toward Romania's foreign policy, Linden considers that it is related to a variety of factors, such as the soviet perception of a political threat as in Hungary or Czechoslovakia, the state of Sino-Soviet relations, political stability in post-Tito Yogoslavia, Soviet economic relations with the rest of the world, and internal political development in the Soviet Union itself.

Asserting that the domestic economy which supports Romania's international policy itself depends on economic and political factors beyond its control, Linden concludes that "the Romanians have had to learn the lessons, good or bad, of interdependence" because the manner in which they 
will negotiate this matter "will determine the overall direction of Romania's foreign policy for this decade."

Writing about the chances of a military

confrontation between Romania and the Soviet Union in the future, stephen Fischer-Galati affirms:

Unless contemporary Soviet-American relations deteriorate much further there is little likelihood of military confrontation between Romania and its allies. Nor is Russia likely to support a military coup against Ceausescu unless conditions in Romania were to become comparable to those prevailing in Hungary in 1956, in Czechoslovakia in 1968, in Poland in 1980 or, alternately, significant changes in soviet policies were to occur. 86

Summing up, it can be stated that the consensus of opinion expressed by the majority of the authors presented in this chapter reveals the main issues concerning Romania's past, present and future dissidence. First, it appears that more research is needed at the individual state level in Eastern Europe, in order to increase the amount of information required for comparative studies or generalizations. At the same time an emphasis should be accorded to the relationship between domestic and foreign policy which provides a better understanding of political realities in each communist state.

Second, there seems to be little doubt in the opinion of specialists in the field about the dominant role played by the Soviet Union in Eastern Europe. It was 
stressed that although the methods of control have in time become more subtle and sophisticated, the basic Soviet goal of domination has remained unchanged. Diversity and tolerance, however, cannot be substituted for independence and liberty. Unfortunately, according to some views, the struggle for independence of East European states has very little chance of being helped by the West.

Third, while Romania's external policies may have irritated the Soviets, it has also been characterized as one of the most rigid and restrictive polities in Eastern Europe. Its dissidence originated in economic reasons in the early 1960 s when the country refused to accept the Soviet policy of supranational planning and international economic integration through CMEA. In analyzing the phenomenon, some authors have distinguished two stages of development. In the first stage, which began in the early 1960s, Romania promoted a policy of national economic development, achieved through a higher level of utilization of its natural resources in conjunction with a reorientation of its external policy to the West and the Third World in order to obtain the credits and trade needed for the rapid process of industrialization and modernization pursued against the Soviet will. This economic rebelliousness was supported ideologically by the "Declaration of Independence" 
which stressed the right of sovereignty and domestic autonomy. During the same stage, taking advantage of its role of mediator in the Sino-Soviet dispute, Romania extended its relations with China, Yugoslavia, and other non-aligned states. These circumstances contributed to lessening the country's dependence on the Soviet Union and created an image of autonomy abroad. The second stage, which started during the mid-1970s, was characterized, according to some views, by the negative impact of the world economic crises upon Romania's economy. The economic setback which forced the country into economic compromises with CMEA, was accompanied by a changing process of international circumstances that made Romania's arbitration role in intra-communist quarrels less significant for external affairs. Internally, the growing economic difficulties have spurred popular dissatisfaction and labor unrest. Trying to avert the situation, the RCP resorted more often to nationalism which, in some opinions, is used for diverting the people's attention from internal conditions and for maintaining a Stalinist internal policy, including the cult of personality.

Fourth, with one exception, the authors agree that Romania's dissidence was genuine, although limited in its manifestation. In fact these limitations, together with the country's internal stability, were considered by the majority of the authors as the major reasons for soviet tolerance toward Romania's deviant foreign policy. 
Characterized as partial alignment or semiautonomy, Romania's dissidence was interpreted not as a desire of separation from the Soviet bloc, but rather as an attempt to obtain more room for maneuver within a permissible framework. Soviet military intervention was avoided, according to these views, not only by observing the limits of tolerance imposed by bloc membership and by maintaining a tight internal policy, but also because Romania centered its foreign policy around the national sovereignty issue. In so doing, it presented the soviets with the prospect of a national war in defense of the homeland.

Fifth, the authors unanimously express their views that given the increasing difficulties that Romania's economy has experienced since the mid-1970s, its ability to maintain an independent foreign policy has become increasingly limited. The struggle for survival, they said, would lead the country closer to the Soviet Union and CMEA, forcing it to reconcile its position within and with the Soviet camp. This fact, in turn, would undermine not only its economic independence but its ideological stand as well. According to this view, Romania's example as a maverick of the Soviet bloc will continue to lose its potential attraction for imitation by other East European countries. 
PART II

PARTY CONTROL IN ROMANIA

It has been hypothesized that a vital reason that explains the absence of Soviet military intervention in response to Romania's autonomous foreign policy has been the latter's internal orthodoxy. The RCP has maintained overall control of all social activities in Romania, a policy much approved by the Soviet union. Why has this policy met the Soviet union's approval? Largely because it included features characteristic of the Soviet type of communism. These include the following:

1. Tight internal control by the communist party over all sectors of society, enabling the firm repression of any challenge to its authority.

2. A single mass communist party which is authoritarian, monolithic and strictly hierarchical, and which transforms all other social organizations in means of implementation its political decisions.

3. An absolute party leader who concentrates in his hands the entire political power of the party and the state. 4. An ideology that justifies the party's leading role in society. 
Part II of this study focuses on the examination of these features. The analysis begins with the Party's internal control, considered here as being the most important element in deterring soviet military intervention in Romania. This position is based on the following considerations:

a. For the Soviets, a single, authoritarian, communist party led by a strong dictator is no guarantee of the acceptance of Soviet leadership, as the examples of China under Mao, Yugoslavia under Tito, and Albania under Hoxha have shown. The Soviet Union has vehemently condemned all these states for following a deviationist path, regardless of the fact that their goals were communist. b. Promoting a communist doctrine is not a sufficient condition for passing the soviet norms of acceptability if the ideological position differs from that of the Soviet Union.

c. Even supposing that the party follows the Soviet ideological pattern, such theoretical adherence is still not a sufficient guarantee for the Soviets. What will convince them in this matter is the way a party applies in practice what it professes in theory. In other words, the proof resides in the character of the internal policies which determine concrete and visible social effects. The closer the similarities between these internal policies and those existing in the Soviet Union, the better the chances for the 
party to be accepted by the soviets.

These criteria are generally valuable for every communist state, and especially so for those in Eastern Europe. The RCP's leadership realized that its questionable foreign policy would not be tolerated by the Soviet Union unless there was convincing evidence of loyalty to the Soviet Union and the socialist camp. And what better evidence could it offer than to emulate Soviet methods of domestic control? Thus, for the RCP the condition for remaining acceptable within the Soviet bloc while pursuing an independent foreign policy was to enforce domestically a rigid overall control. By complying with this main Soviet demand, to which the other three factors were added, the RCP was able to surround itself with a defensive line against Soviet military sanctions. And, for two decades, it has worked. 
CHAPTER THREE

INTERNAL CONTROL

Party control in Romania is a phenomenon so generalized and so conspicuously displayed that, almost without exception, foreign observers characterize Romania as the most tightly controlled polity in Eastern Europe. The omnipresent character of this policy makes it impossible to examine here all its forms of manifestation in Romanian life. Therefore, the analysis will concentrate only on the following political features:

a. Repression of dissidents;

b. Repression of workers' rights;

c. Cultural control and censorship; and,

d. Opposition to emigration.

a. Repression of dissidents.

Romanian tradition is not much inclined to violent resistance or open rebelliousness against oppression and domination. Rather than bursts of anger Romanians have dealt in the past with foreign domination or local tyrants by adopting a passive attitude and practices that corrupted and undermined the exploitative authority. This approach has also been followed under the communist regime, although sporadic forms of opposition have occurred, especially 
during the first years of the communist dictatorship. These acts of opposition were spontaneous and unorganized, reflecting mostly workers' dissatisfaction with wages and working conditions.

The intellectual dissent that first attracted international attention occurred in Romania in 1977. At the beginning of that year, a small group of Romanian dissidents led by the writer Paul Goma wrote to the 35 nations that were to meet in Belgrade to review the results of the 1975 Helsinki Conference, urging them to pursuade the Romanian government to apply the provisions of the Helsinki Agreement it had signed in 1975, and in particular the so-called "Basket Three" provisions regarding human rights. The main controversy centered around the relationship between individual freedom and society's needs. Individual rights apart from the collectivity were interpreted by the Party as bourgeois-liberal democracy. The dissidents adopted the position that the modernization of society with corresponding improvements in material and social conditions, should provide individual liberties. They stressed that the Romanian constitution guaranteed freedom of speech, of religion and of assembly, but only on condition that they not harm socialist society. Citizens are not allowed openly to question the correctness of economic or political decisions or to refuse to participate in the building of the socialist order. The dissidents did 
not reject socialism per se, but rather the limitation of personal choices in the relationship of the individual to the state.

When the document gained international attention, the regime's reaction was to give its signatories exit visas to leave the country, hoping thus to avoid an embarrassment on the eve of the Belgrade Conference. Surprisingly, the effect of this tactic was contrary to the government's expectations. Paul Goma refused to leave the country, and the document suddenly drew large popular support. Even though some of the 150 signatories of the document were more interested in getting permission to leave the country than in human rights issues, Paul Goma became the symbol of the human rights cause and refused to buy his literary rehabilitation with his exit from the country. He continued to receive messages of support from different parts of the country, despite the fact that the Romanian press did not print a single word about the dissent. ${ }^{2}$ The government perhaps hoped to isolate the case and deter the diffusion of dissident ideas to other parts of the country, thereby avoiding the growth of the movement against the Party's authority.

Less than two months after its open emergence in Bucharest, the Romanian government crushed the dissident group. Goma was arrested, and many of the signatories of his document were interrogated, threatened and beaten by the 
security police. Released from prison after six weeks, Goma refused to meet foreign journalists, kept a low profile and finally left the country.

Like Sakharov in the Soviet Union, Goma considered that a campaign for human rights had to be pursued from inside rather than from outside the country. He refused, like Sakharov, to compromise with the Party and remained loyal to his convictions. However, his firm stand was rapidly crushed by the regime's repressive actions. The RCP could not affort to have an internal dissident group which would call into question its capacity to keep internal order, a condition that weighs so heavily in Soviet eyes. The moment it became clear that the Party's tactic of buying his silence had failed, the decision to crush the movement was executed without delay. By forcing Goma to leave the country and dismantling the dissident group, the RCP restored "order", proving to the Soviets proof of its ability to maintain firm internal control.

A different aspect of the Romanian dissent movement was represented by the members of the Baptist Church who accused the government of harassment and religious discrimination. A document containing their major complaints was read on Radio Free Europe in 1977. In response, the regime promptly arrested the signatories of the document, who were detained and beaten by the security police. ${ }^{4}$ The RCP's attitude toward religion follows the 
same line as that of the Soviet Union: religious institutions are perceived as potential havens for opposition to the Party's authority. Consequently, they are surrounded by permanent suspicions, are limited by restrictive laws and are subject to constant police control in order to prevent an anti-communist orientation. In addition, religion and religious organizations are manipulated by the government for the purpose of national policy.

Following the Soviet Union's example, where preferential treatment is given to the Russian Orthodox Church (which has the largest religious group and is associated with Russian nationalism), in Romania the Orthodox Church benefits from similar treatment. The explanation is first, that the orthodox faith includes the largest number of religious members among the Romanian population, and second that the Romanian Orthodox Church, unlike the Catholic Church in Poland, does not have the moral authority of mobilizing national resistance against the communist regime. Being more docile, and having religious leaders willing to cooperate with the regime, the Romanian Orthodox Church is better controlled by the Party than is the Catholic Church in Poland. On the other hand, the RCP is not willing to extend the same treatment to smaller religious organizations such as Baptists, Adventist-Reformists, or other religious groups. The reason 
for this is not only that they represent a religious minority, but also because their congregations usually meet in private places and their religious leaders are less cooperative with the regime. The RCP is thereby deprived of the possibility of controlling their activities.

However, when a dissident movement originates in these smaller religious organizations, the Party cannot repress it on religious grounds because Article 30 of the Romanian Constitution:

guarantees all the inhabitants of the country the liberty of having or not having a religious creed, the religious cults being fully allowed to organize themselves and function freely... The law forbids all discrimination between the citizens of the country, on religious grounds and punishes religious hatred and any actions aiming at obstructing the free practice of cults.5

So, the Party crushes dissident movements by resorting to accusations that imply that the dissidents are in fact not motivated by religious freedom but by greed and egotism. They are also accused of being influenced by foreign propaganda and of being engaged in subversive and espionage actions against the country.

This style of dealing with dissident problems proves again that Romania follows the same lines of internal repression so characteristic of the soviet method. By advancing in this direction even the notion of freedom seems to change its normal meaning; as one dissident put it, "to stay out 6 of jail is a very important kind of freedom for anyone." 
b. Repression of workers' rights.

Socialist Romania has not experienced a massive outburst of popular dissatisfaction or industrial proletarian unrest, as did Poland. There are however, some examples of open conflict between the workers and the RCP. The miners' strike in the Jiu Valley in 1977 was one. 7 The event began in August 1977, in Lupeni, a mining community, where miners blocked the mine entrance and displayed publicly their discontent with the Party's policies, which were blamed for the shortages of food and consumer goods, and for inadequate housing and pension provisions. The miners also protested against the penalties imposed for not fulfilling production plans. The strike rapidly spread to the entire coal mining area of the Jiu Valley, encompassing several mines and involving about 35,000 miners. A petition containing their demands was presented to Ceausescu who arrived on the scene amidst a very tense situation. He agreed to grant some of the miners' demands and made a number of promises for satisfying them. For two weeks the conditions were indeed improved. Then, in the beginning of September, military troops were moved into the area and plainclothes officers from the security police entered the mines disguised as miners, in order to prevent and diffuse any resumption of the strike. The leader of the strike was seized by the security police and removed from the area. In retaliation, up to 40 percent of the miners' August salaries 
was deducted for non-fulfillment of the production plan.

As usual, the government did not comment publicly upon the event, and the press did not mention the strike at al1. The Party's policy was to isolate the event immediately and cut off channels of communication and contact with the area. It was thought that dissemination of information about the strike carried a direct danger for the RCP's internal control because other areas of the country with smoldering popular discontent might become active because of the miners' example. At the same time, Party's activists throughout the country were instructed to minimize the strike and downplay its significance whenever the subject arose in public discussion.

First details of the event reached the outside world months after it had occurred. The reaction of Romanian officials to Western reports was first to deny it and then to refuse comment. When Ceausescu visited the mining area again on November 9, 1977, he did not make a single remark about the strike in his speeches. The Romanian News Agency reported instead that "Ceausescu was welcomed with particular warmth, cheers and flowers."

Expressing the opinion that Ceausescu's position was not much affected by the strike, one Western observer noted that "he handled it very nimbly. He backed off where he had 10 to but otherwise clamped down." According to Amnesty International's Group 113 in Chicago, "up to 4,000 miners 
were forcibly removed to labor and resettlement camps throughout Romania after taking part in [the] strike in the Jiu Valley in August 1977." 11

For a society that claims that its first priority is to fulfill the needs of the people, the Jiu Valley strike stands as an eloquent example of the enormous difference between the RCP's propaganda and reality. The reasons for the strike were nothing other than those very needs that the Party had failed to provide to the people for so long. Many of these needs were basic human needs. Instead of satisfying them the Party's response was to arrest the strike leaders, move military troops into the area, and spread thousands of strikers to labor camps and forced settlements elsewhere in Romania. It seems from this example that no price is too high for the maintenance of the Party's unchallenged authoritarian position. By acting ruthlessly and swiftly against the miners, the Party gave an unmistakable warning to other industrial workers that it will not tolerate any form of opposition to its domestic policies. And indeed there were some reports of prompt police repression against railroad and metallurgical workers who tried to voice their discontent in Bucharest and in other parts of the country. ${ }^{12}$ The way the RCP has handled these major conflicts with workers must surely have been perceived with great satisfaction in Moscow. It certainly must have enhanced the RCP's credit in soviet eyes because 
it gave assurance that Romania would not permit the development of a "Solidarity-type" movement that subsequently so troubled the Soviets in Poland.

c. Cultural control and censorship.

In pursuing their socialist and communist goals, communist systems must create a new communist culture which will be used as an instrument in shaping the new society and socialist individuals. Like other East European countries which came under communist rule through imposed revolutions under Russian occupation, Romania was forced to adopt communism in its highly Russified Stalinist form. Although the country's political and cultural heritages were significantly different from Russia's, the Soviet model was forcibly transplanted into Romania's life.

In the cultural realm this forced process of assimilation has resulted in the restructuring of the entire educational system after the Soviet model. The laws of natural sciences were reinterpreted in the light of dialectical materialism. Art and literature were "purified" of bourgeois remnants and raised to the highest level of socialist realism from which they could truly serve the cause of communist society. A methodical attack was started simultaneously against religious convictions and "decadent" Western ideas of social behavior, which were considered to be dangerous factors that undermined the process of 
creating the "new socialist man." It is noteworthy that one of the goals of this process was to "free" people from their attachment to nationalistic sentiments and to cultivate a new attitude of socialist patriotism, meaning loyalty to the cause of socialism and its leading "star", the Soviet Union.

It was not until the de-stalinization era started by Khrushchev in 1956, that new tendencies of diversity started to challenge the rigid pattern of Russian communist political culture. In order to make the social order more acceptable to the masses and to increase at the same time their legitimacy, the communist parties started to blend elements of the national cultural heritage into the new socialist culture such that it gave each communist culture a mark of distinctiveness.

In Romania the process of enhancing socialist culture with traditional values such as patriotism, collectivism and sacrifice for remote national goals, was accompanied by an effort to eliminate what was considered the negative heritage of presocialist culture. Among the condemned manifestations were national chauvinism, localism, egotism, corruption and loose morals. At the same time considering that Romania is a multiethnic society the cultural elements of Hungarian and German origin were absorbed into the new socialist culture. The result of this process has been that the initial Russian model has been transformed into a cultural amalgam that bears a national 
imprint.

However, the de-Stalinization campaign soon began to reveal some unpredictable effects. The trend of liberalization in art and literature in communist countries, including the Soviet Union, tended to grow beyond the control of the respective parties. Once the door for criticism was opened the line between what was acceptable to the regime and what was not, became very difficult to hold. Criticism went so far that it challenged the legitimacy of the RCP's social control, and demanded greater freedom for cultural activity and the liberalization of art from politics and ideological goals. Even more dangerous for Party control was the solidarity among members of the cultural intelligentsia:

Cultural circles and clubs... became centers of independent literary, social, and ultimately political initiative, which accelerated the disintegration of party controls and which provided a common meeting ground for those who wished to bring about real social and political changes.13

Sensing the threat that this development could pose to his political power, Khrushchev himself in 1962 reinforced Party control in the cultural realm and restored the ideological limits of cultural expression. From that time on, it became clear to the Soviet satellites that any significant deviation from the soviet line in this field would lead to a confrontation with the Soviet Union. The repression of the pluralistic tendencies of expression that blossomed within the intellectual Czechoslovak movement in 
1968, proved the existence of the soviet limits of tolerance.

Learning from this lesson, the RCP's policy of promoting a socialist culture heavily laden with Romanian nationalism, was carefully balanced by close cultural control. This trend became obvious in the summer of 1971 when Ceausescu, after a long trip to China and other Asian communist countries, launched the so-called "mini-cultural revolution." It was an integrated part of the ideological and cultural offensive designed to raise political consciousness and cultural awareness at the mass level. The cultural program emphasized that art and literature should take their inspiration from socialist ideals and base their form of expression on Marxism-Leninist ideology, aiming to raise the consciousness of the new man. It was the same view that had guided Soviet literature and art from the time that Khrushchev had expressed it:

Literature and art are part of the whole people's struggle for communism... The highest social destiny of art and literature is to mobilize the people to the struggle for new advances in the building of communism. 14

Ceausescu expresses it thus:

Literature is called upon to depict convincingly the new human conditions in our society, the ideals... of the new man... Literature should strengthen... the superiority of the socialist system.15

The Party's cultural program calls upon the union of writers, composers, plastic artists, film producers, artists, literary and art critics to organize debates on the 
ideology and cultural policy of the RCP, to study the norms and principles of Marxist ethics and esthetics, and to promote work with a revolutionary and patriotic character. It follows that in the Party's view art is not based on the spontaneous and free inspiration of its creator; it has, instead, a special meaning which justifies its submission to political control.

The same ideas appear in the soviet concept:

For the artist who truly wants to serve his people, the question does not arise of whether he is free or not in his creative work... the true representation of life from the point of view of the Communist 'partiinost' is a necessity of his soul. 17

So, for the creators of art the framework seems to be well established by the Party's indications. Said Ceausescu: "We do not need several philosophical concepts in Romania, but only one: the historic and dialectic materialism." ${ }^{18}$

This control and censorship imposed upon artistic creation has totally blocked the channels of exchange for new ideas in artistic expression and has threatened directly the creators' artistic integrity. They have, out of conviction or fear, to subordinate their work to the Party's demand. The few who have had the courage to oppose directly the cultural dogmatism of the Party and to complain against its censorship have been harshly repressed, have been accused of promoting elitism and have been excluded from artistic unions. One of them, the writer Paul Goma, became a central figure in the campaign for human rights. 
Trying to present its artistic control and censorship in a democratic light, the Party has promoted the idea of bringing artistic creation "down" to the masses. "Theater performances are now often staged in factories and offices, and workers and peasants sit on review boards that examine the merits or demerits of books, plays and films." But the party is watching not only what is produced inside the country in the cultural field: it also decides what the Romanian people should know regarding foreign culture. According to the Party's directive, presenting foreign culture will be in accordance with the Party's principle of safe-guarding the socialist education of the 20 masses. This means, for example, that no subscription to a cultural magazine or periodical from abroad is allowed without the Party's approval; no book can be translated into the Romanian language and no movie can be seen, without a rigorous screening for anti-communist hints.

To have total control over the country's culture, the Party has accorded an important role to the participation of the masses. A national festival called "Song to Romania," is organized every two years in the form of a national artistic contest starting from the smallest communes and villages up to the final stage in the country's capital. Throughout, hundreds and thousands of amateur artists, alone or in groups, sing or recite praises to the Party and its leadership. From beginning to end, every 
stage of the festival is controlled and approved by the Party: "Every field, down to the last commune and last dance or cultural ensemble, must carry out its activities under the direct leadership of party bodies and organizations." ${ }^{21}$ The purpose of this mass culturalization under strict Party supervision, is the final goal of socialist culture, the creation of a new socialist man: "The National Theater, the Romanian Opera House, and up to the last cultural house in the remotest commune or village, must become a revolutionary, patriotic center of shaping the new man."

An important part in the development of the Romanian socialist culture is played by the press, radio and television which are also under total party control and censorship; "The press, radio and television should be an efficient platform of our socialist democracy, to serve the participation of the masses 23 in debating the party's policy in the leading of society." Although in theory the mass media are supposed to take a firm position against the negative aspects from society's life, in reality no article is printed in the local or national newspaper and no news is transmitted on radio or television without the Party's approval. And this approval will never come for subjects such as dissidents, workers' revolts or popular dissatisfactions that will damage the Party's image. Through its levers of control and censorship the RCP 
has been able to shape in the last twenty years a socialist culture whose lines of development have been similar to those that have existed in the Soviet Union, except for the nationalistic aspect. Romania's highly charged

nationalistic campaign can hardly be approved by the soviets if they are to maintain the unity of the socialist camp. However, since Romania has thus far avoided Soviet military sanctions for its nationalistic overtones, some explanation in support of the hypothesis of this study is necessary for this particular aspect.

First, the nationalistic feelings in general and the anti-Soviet resentment in particular have been strictly controlled inside the country by the RCP. As the responses to the Soviet invasion of Czechoslovakia in 1968 and the Soviet-Romanian territorial dispute over Bessarabia in 1976 have demonstrated, anti-Soviet feelings have been carefully orchestrated by the RCP even though they might have initially appeared naturally and spontaneously. They were allowed to rise in intensity up to a level at which the Party could obtain its desired popular support. After that, anti-Soviet expressions were firmly framed and cooled and no other revivals were permitted. Once the Party position was backed by large popular support, the issue which stirred the emotional uprising was removed from the front to the back burner and revived only from time to time when the Party needed a new boost of mass support for its policies. 
Second, the Soviets might understand Ceausescu's political play with Romanian nationalism in maintaining the Party's legitimacy. And since the RCP maintains Romania's internal orthodoxy in part through appeals to nationalism, the Soviets are willing to accept some overcharged nationalistic manifestations, as long as they are under the Party's control.

d. Opposition to emigration.

Following the Helsinki Agreement that emphasized the issue of human rights, Romania's regime has experienced an increased pressure from a large number of people who have applied for exit visas to the West. This phenomenon has reflected a massive manifestation of discontent with the RCP's position on the issue, which has been interpreted by the regime as the consequence of Western ideas that have penetrated Romania's life and "polluted" its moral climate. When human rights are used as a basis for emigration to the West, the Party rejects the humanitarian aspect, claiming that it is a Western tactic intended to undermine Romania's socialist development by luring people abroad to an easy life. Speaking about this problem at the Twelfth RCP Congress, Ceausescu declared:

The party will be firm in its fight against the chauvinist and nationalistic propaganda of reactionary circles abroad, against the falsification of the situation in our country, against the attempts to mislead the working people of other nationalities. 24 
For Ceausescu, who strongly emphasizes the organic ties that should exist between the individual and the society, the desire for emigration is a condemnable act of immoral behavior that endangers his personal historical mission: "The issue of emigration probably appears to be limited to treason or abandonment of the common nation- building effort; in a way, abandoning 'the ship' is a form of violation of the General Secretary's personal human rights." Ceausescu has made clear that the Romanian government will not permit any mass emigration and he has disapproved of the tendency of individuals to $100 \mathrm{k}$ for solutions to their problems outside the fatherland, instead of solving them inside the country for the common benefit: The place of our citizens regardless of their Romanian, Hungarian, German or Jewish nationality is here, in the common effort of all the people for building a truly free and happy life in which everybody could enjoy the socialist civilization. 26

Mentioning that the party will continue to solve in a humanitarian spirit the reunion of families, Ceausescu has emphasized, nonetheless, that foreign propaganda initiated to attract Romanian citizens from ethnic minorities, especially Germans, has nothing in common with humanitarian issues. To Ceausescu, such efforts represent the attempts of big capitalist enterprises to obtain skilled labor for a cheap price. "What kind of families' reunion is that in which people lived in Romania for hundreds of years?" he 27 asked. To attempt to lure these people from their land in 
which they were born and from the environment to which they have adapted for so long a time, represents in his opinion "an act of inhumanitarian family disintegration." ${ }^{28}$ In his view the problem of family reunion can be solved in a more proper way by having the respective family members from abroad, return to Romania. Thus, according to the Party's view, there is no reason for Romanians to emigrate:

We do not encourage anyone under any form to leave Romania. We ensure jobs and equal opportunities to all of our citizens... Therefore there is no justification whatsoever for anyone leaving his country to work abroad. 29

The RCP's restrictive policy on emigration is reflected not only in its statements but in its practice as wel1. The process of issuing exit visas involves an exasperating waiting time of two to three years during which job discrimination, harassment and police interviews are common practices. By promoting this policy the RCP is totally in tune with the Soviet Union's position, where hundreds of thousands of people, especially Jews, encounter even worse treatment in response to their requests for exit visas.

In conclusion, it may be reiterated that the RCP's internal control is an undeniable reality proved by concrete and visible political actions. The firm and harsh repression against intellectual and religious dissent movements reflect clearly that the $\mathrm{RCP}$ is not willing to 
accept any form of individual freedom that can challenge its authority. The same repressive policy applied against workers' discontent has demonstrated that the Party will not tolerate any organized opposition that threatens the maintenance of its domestic policies. In the cultural realm the Party has totally subordinated Romanian culture to its communist ideology and through censorship has culturally isolated the country from the West. Finally, by opposing emigration and ignoring the documents it signed at the Helsinki Conference in 1975, the RCP proves its dictatorial internal policy which disregards certain human rights. All these facts demonstrate that the RCP holds a firm and unchallenged domestic control and is totally committed to the communist cause. This evidence represents a line of strong defense against Soviet military sanctions. Indeed, it is reasonable to assume that the Soviets will think twice before deciding to invade the tightest polity of their empire whose internal features resemble so much their own society. 


\section{CHAPTER FOUR}

\section{THE PARTY}

According to the Constitution, the leading power of Romanian society is the RCP. Under Ceausescu this leading political force has been strengthened, permeating all aspects of the state and the society. This chapter examines how the Party was able to accumulate such power and use it as a deterrent against the soviet military sanctions. Two aspects will be analyzed in this regard:

a. Consolidation of the Party's internal organization. b. Subordination of the state and social organizations to the Party.

a. Consolidation of the Party's Internal organization. In order to maintain and enlarge its autonomous foreign policy and at the same time to prevent soviet military sanctions for its external behavior, the RCP has pursued two directions of development:

1. Increase its representative character by becoming a mass organization, and

2. Consolidate its organizational unity.

The reasons behind these decisions were, first, to show the Soviets that the RCP's decisions and actions represent 
the will of the Romanian people, and thus in any invasion the Soviets will face national opposition. Second, by strengthening its monolithic character the Party's aim was to increase its authority as the leading political force in society

a.1. Consolidation of the Party's status as a mass organization.

At the Ninth RCP Congress in 1965, the Party had 1.5 1

million members. During the next two decades this ${ }_{2}$ number uniformly increased, reaching 2.5 million in $1974,2.9$ 3

4 million in 1979, and 3.5 million in 1984. A concerted effort has been made to adjust the membership composition to the structural changes that have occurred in Romanian society. Thus, according to statistical data for 1984, workers represented 55 percent of members compared with 44 percent in 1965, indicating the Party's intention of maintaining its "working class" character. Peasants represented 15 percent of the Party membership, the intelligentsia formed 20 percent, and the remaining $10 \%$ is formed by retired people, housewives, students and military personnel. An increased membership has been registered for women, who formed 32 percent of the Party compared with less than 28 percent only four years before. An adequate ratio has also been maintained in terms of ethnic composition: 90 percent Romanians, 7 percent Hungarians, .7 percent Germans; 
the remaining came from the other nationalities.

\section{As Ceausescu has stated, maintaining a proper}

composition of the Party membership will remain a permanent objective for the future:

We must continue to pay particular attention to the promotion of cadres from the working class, because it is now the most numerous force of our nation... Greater attention will have to be paid to the promotion of women to positions of responsibility in all domains.... Particular attention has to be paid to the harmonious blending of the work of elderly cadres with the elan and enthusiasm of the young cadres.

Parallel with increasing its membership, the RCP has also extended its territorial coverage. At the end of 1984, Party organizations were present in each county, municipality, town, and commune in Romania; there were 6,344 Party organizations led by committees in enterprises, institutions and agricultural units, 72,735 basic organizations, and 12,964 Party groups, "capable of mobilizing communists and other working people to commendably fulfill the party decisions." ${ }^{7}$

Consolidation of the Party's status as a mass organization could not be accomplished without a large number of qualified cadres, responsible for the selection and recruitment of the new Party members. Therefore, particular attention has been paid to the training of the cadres. As a result, between 1974 and 1979 "nearly 43,000 activists have graduated from the party schools of various level."

It appears clear from this policy that a twofold 
purpose was attempted to be achieved by the Party; first, the broadening ofthe basis of its membership by attracting a large number of people from all social categories in a proportion that would give the Party a social structure similar to that of Romanian society; and second, the strengthening, on this basis, of the Party's identification with the Romanian population at large. As was reported at the Thirteenth RCP Congress in 1984, the Party's membership included more than 22 percent of the total adult population, and almost 33 percent of the total active population. However, one aspect should be emphasized in this regard. If the Party is indeed the vital center of the entire nation, the highest echelon of the revolutionary force, "animating all creative energies and harnessing the genius of the entire Romanian people," then this should be reflected in the quality of its membership. ${ }^{9}$ As society's vanguard force, the Party's work should be very efficient. This requires in turn a limited size and highly motivated members. To keep up its prestige the party needs to maintain its membership standard at a high level; membership should be a privilege and honor worth striving for. Yet, the Party cannot escape the dilemma of increasing its representative character by including a large number of people, on one hand, and maintaining its proper size and membership quality, on the other hand.

Undoubtedly, one result of facilitating admission to 
the Party was the entrance of numerous opportunists whose conduct has directly affected the Party's revolutionary standards. These concerns were clearly expressed by Ceausescu when he criticized the attitude of "passivity and lack of enthusiasm" spread among party members and activists, and condemned the manifestations of "bourgeois-landowner mentality, "emphasizing personal

material gain at the expense of the societal collectivity. Thus, Ceausescu said, the further growth of Party membership should be a selective process: "The high title of communist should be awarded only to those who prove they know to fight for the implementation of party's policy and who manifest a 11 revolutionary spirit." He stressed that the high title of communist implies hard work and dedication: "Party membership does not give any additional rights; on the contrary, it means higher duties, boundless responsibility and devotion in the implementation of party's policy." To what extent this characterization accurately depicts the 3.5 million members of the RCP remains a very complicated question. What is clear, however, is that under Ceausescu's leadership the RCP has achieved indeed a significant numerical and territorial growth, advancing on the road of becoming a mass party organization.

a.2 Consolidation of the Party's organizational unity. In order to be able to pursue an autonomous foreign 
policy in general, and to maintain a firm stand on the issues related to the Soviet Union in particular, the RCP has needed a united front of action. This vital objective lay behind the Party's efforts in the last two decades intended to consolidate its monolithic character. The Party's basic organizational principle for serving this scope is democratic centralism characterized by a rigid hierarchy and centralization of power. Through it, the Party's vast organizational network from the basic territorial units up to the Central Committee is interconnected in an operational system in which information and commands are interchanged in an upward and downward flow respectively. While in theory all party members are entitled to participate in the decision making process, once a decision is made the minority must subordinate its views to those of the majority, and compliance is expected with orders coming from the top.

The Central Committee in Bucharest, supervises numerous interlocking committees and directorates at the central level which are charged with the transmission and implementation of the Party's decisions down to the last organizational territorial unit from where the RCP activists carry the messages to the general population. It becomes clear that the Party's capacity for mass mobilization depends directly on the efficiency with which this extended organizational network operates on a daily basis. To improve its performance, the Party's structure 
has undergone many changes, especially at the top levels. Thus, at the National Conference of the RCP in July 1972, the Central Committee was expanded from 165 to 185 full members and from 115 to 135 alternate members. ${ }^{13}$ In order to prevent "routine performance and promote constantly a new revolutionary spirit of work," the Eleventh RCP Congress held in 1974 made some structural modifications. ${ }^{14}$ It was established that election to a Party committee would be possible only for those candidates who had a certain length of Party service and previous experience in a leading organization. This principle, it has been said, would be applied to all leading bodies of the Party from the top to the bottom. Important changes have been introduced also at the top Party level. It was decided that the Executive Committee of the Central Committee would be called the Executive Political Comittee of the Central Committee because "this name corresponds better to its role of leading the entiresparty activity between Central Committee plenums." At the same time the RCP statute includes a new provision concerning the creation by the Executive Political Committee of a five-member Permanent Bureau whose task is to lead current activity. In 1977, the Permanent Bureau was enlarged to nine members.

Ceausescu has used these structural changes to promote his relatives and close associates to top Party 
bodies thus increasing the concentration of power in his hands. Although this tendency toward elitism has accentuated the leadership's alienation from the rest of the Party, an increased propagandistic effort has been made to present it as an integrated part of a democratic political structure. This aspect appears very obvious during the RCP Congresses, which are held every five years. The entire election process of the top organizations is carefully orchestrated to be in accord with the principle of democratic centralism. Each Party organization which elects its delegates to the Party Congress is "assisted" by a representative from a high ranking organization. The purpose of this assistance is to ensure the election of the "right" delegates to the next stage of the elective process. The effect of this proceeding of successive selections is that the quality of the final delegates that form the Congress will virtually pose no threat of opposition to the "election" of the new Party apparatus which is already designed by the elite.

It appears clear then, why a rigorous discipline and a strict hierarchical subordination imposed by the statute represent vital issues for the Party's existence: through them the external face of democracy is preserved, while the possibilities of internal opposition to the leadership are limited. This practice helped ceausescu to consolidate his 
legitimacy within the Party; starting with the Tenth RCP Congress held in 1969, he has been elected and reelected as Secretary General at each successive Congress, not only by the Central Committee (like the other First Secretaries in Eastern Europe) but by a unanimous vote of the entire Congress. Ceausescu has exploited these events by using them as proof of the confidence which exists between the RCP and its leadership. The message carried by these political displays is to discourage any eventual soviet attempt to use internal Party discord to interfere in Romania's affairs.

4.2. Subordination of the State and Social Organizations to to the Party.

In order to have total control over the country's internal and external policies, the $\mathrm{RCP}$ has needed not only to enlarge its representative character and strengthen its organizational unity, but also to eliminate the competition for power posed by other state and social organizations. The subordination of the state to the Party was the fundamental step made by Ceausescu in his ascendancy toward absolute power in the country. At the same time the elimination of the state-party dichotomy deprived the Soviet Union of the possibility of exploiting the process of struggle for power between the Party and the state, thus safeguarding Romania's independent course. 
b.1. Party and the state.

At the National Conference of the RCP held on

December 6, 1967, Ceausescu presented a report for territorial and administrative reorganization in Romania. This proposal became the Administrative Reorganization Law in February 1968 and replaced the Soviet model imposed in Romania in 1950 with a new organizational system based on 39 counties as the basic territorial-administrative units. The Party's justification for the reorganization was that it sought decentralization and increased opportunities for mass participation in local administration. What in fact was realized through this reorganization, was a fusion of the Party and state functions at the national level.

What Ceausescu had established at the top, after the Conference in 1967--namely unifying in his person the head of the Party and president of the state--was replicated down along the lines of authority to sub-national levels. Through this reorganization the Romanian government became structurally parallel to the Party at each hierarchical level. Party and state organs at the national level, such as the Grand National Assembly and the Council of State, were replicated at the local level in the form of People's Councils and Executive Committees. In accordance with Ceausescu's dual status as Secretary of the Party and President of the Council of State, at the sub-national level the president of the People's Council of each county became 
simultaneously the first secretary of the parallel local party organization.

A brief examination of state institutions and subnational government might be helpful in understanding the interlocking nature of the Party and the state in Romania.

i. State institutions.

Under the Romanian Constitution the main state institution is the Grand National Assembly, defined as the sole source of power in the Romanian government. It is a unicameral body consisting of 465 deputies, elected every five years. Second in importance is the council of state, a permanent legislative body of 22 members. Its head is the President of the Republic, who has at his service a staff organization called the Presidency of the Republic. Third, and subordinated to the Council of State, is the Council of Ministers, a policy-implementation body which directs state administration and daily governmental operations. Its head is the Prime Minister.

One of the basic characteristics of the state administration is the principle of double subordination. The dual character of the state and the party organs begins with the Council of State, which became by law an organ of the Party and the state in 1969, and continues downward to local administration. 17 subordination means that all local administrative and technical services provided by central governmental organs 
are subject to supervision and control exercised by people's council officials, who are also top local party personnel.

ii. Sub-national government.

Sub-national government, both in the state and the Party, is organized around the territorial administrative division. There are three levels of sub-national government: counties, towns or cities, and communes. People's councils are local administrative and representative assemblies which are operating at all three levels. As local organs of state power, they are charged with organizing the citizens for participation in solving state and public problems at the local level. As organs of representation and administration at the same time, the local people's councils are used by the RCP as an example of Romania's internal democracy, by suggesting the direct participation of masses in the policy making decisions. Within the people's councils the fusion of political and administrative activities appears more clearly than at the national level. Whereas at the national level political institutions are separated from the administrative ones, the people's councils are housed in the same building with local Party organizations, ensuring in this way a close communication between party and state administration offices. Representatives to the people's councils, or deputies, vary according to the population of the respective territorial administrative unit: from an average of 200 
deputies at the county level to 50 in a commune. Each council has a president and an executive committee. Local problems are resolved by the permanent bureau, formed by the president and a reduced number of high ranking officials. The permanent bureau together with the Party bureau forms a local political elite which is in fact the true government at all three sub-national levels. Holding in his hands the top state and Party positions, the president of the council retains the absolute power which makes him the undisputed local leader.

Thus, Ceausescu's style of leadership, reproduced all over the country, has led to the creation of a sub-national government system which relies on local elites totally subordinated to the "leader" and ready to execute and implement his decisions down to the last functional unit in their area of control. The Party uses this system as an efficient device in the process of transmission, coordination, implementation and control of its decisions. At the same time it enables the RCP to perform a quick mobilization of the entire population if an event such as a military invasion threatens the country's sovereignty. Such a government system then, in which the state is subordinated to the Party, can be interpreted as a defensive measure taken by the Party for the protection of its autonomy against the soviet military threat. 
b.2. The Party and mass organizations:

For the RCP the coordination of mass organizations is one of the fundamental principles of its internal policy. Mass mobilization is a reflection of the Party's degree of popular support and an indication of its ability to lead the society toward socialist and communist goals. At the same time mass organizations are used by the party as propagandistic means for cultivating patriotic sentiments and commitment to defending the country's sovereignty.

There are practically dozens of mass organizations designed for a large variety of interests in Romanian society. Among them are: the Socialist Unity Front, the Trade Union, the Union of Communist Youth, the Union of Students' Associations, the National Women's Council, and the Writers' Union.

The Socialist Unity Front is the largest mass organization in the country and has the role of organizing electoral campaigns for the National Assembly and the People's Council at regional and local levels. According to the Party's view, the organization's main effort should be directed toward uniting "all the forces of our nation under the leadership of the party for strengthening the socialist 18 system."

The Trade Union, which functions as a transmission belt of command between the leadership and the workers, has a significant importance for the Party since it encompasses practically all the workers in the country. Membership 
in the Trade Union is almost unavoidable, since a series of work benefits such as health insurance, vacations, pension, and housing, are directly related to this affiliation. An important aspect in the organization's activity is the existence of workers' councils and the self-management concept. They are emphasized by the government as mechanisms of democratic participation by workers in management decisions. However, the leading role in these councils belongs more to non-elected members (such as the enterprise director, party secretary, chief accountant, young communist league secretary) and less to representatives elected by the workers.

In Romania, there are no national organizations to voice workers' grievances and defend their interests other than trade union organizations. Since "the attempt to form an independent workers' union in Romania has faded under government pressure," the workers must rely only upon their local organization for the resolution of their problems. General assemblies were supposed to be a means of affirming workers' self-management and a place of debating and resolving their needs. They are, in fact, symbolic gatherings where the enterprise's director presents the objectives of the production plan, the need for economies in material, and makes references to work efficiency, to which the party secretary adds the necessity of raising the moral and ethical values of the workers. Operating in this way these meetings have created a sense of a lack of efficiency 
and have resulted in reduced worker interest and participation.

Although the 1977 labor strife among miners in the Jiu Valley was to have produced a new emphasis on selfmanagement and greater "democratization" of the workers" councils, the rhetoric has not been followed by any real 20 decentralization. Constrained by the limited autonomy imposed by the Party, the trade union organizations have proved to be unable to solve the workers' daily problems. Consequently, since the discontent remains, the Party will continue to be confronted by a thorny relationship with the class whose interests it allegedly represents.

The other mass organizations in the country are under the same policy of subordination; the Party is directly interested in increasing its political socialization among youth, women, students, or other professional organizations in order to align their activities with its internal goals. The meaning of "subordination", officially translated as guidance, direction, and control, is greatly facilitated by the Party's strict control and censorship over the entire flow of information and communication within the country and with the outside world. The process is also helped by the RCP's practice of encouraging the development of watchdog bodies and small "vigilante" units which, disguised as "public awareness" or "voice of the public", gather information about the character of social activities that take place 
within the mass organizations or social groups. These watchdog practices combined with the tight social control exercised by the regime's security apparatus, including informants from inside the mass organizations, help the Party to monitor very closely the social organizations" activities. Finally Ceausescu's personal style, characterized by frequent visits all over the country, contributes directly to the subordination process of the social organizations by creating the possibility of a direct communication between the "leader" and the masses.

It can be said, in conclusion, that in the last two decades the RCP has increasingly consolidated its position in Romanian society by enlarging its representative character, while maintaining a strict hierarchical structure through which the state and other social organizations have become totally subordinated to its leadership. Through this policy the $R C P$ has increased its defensive position of autonomy not only by following the soviet internal pattern of practices and methods, but by presenting itself as a strong leading organization with a united front of actions and largely supported by the Romanian people. Through its firm internal control the Party has sent a reassuring message to the Soviets regarding Romania's internal stability. However, at the same time the RCP has expressed its commitment to preserve the country's sovereignty. By using its domestic authority, the Party has presented to the 
Soviets a perspective of national opposition in the event of a military intervention in Romania. By consolidating its leading role within Romanian society, the party has thus contributed to the avoidance of Soviet military intervention. 
CHAPTER EIVE

\section{PARTY LEADERSHIP}

For the last twenty years the RCP has been identified with Nicolae Ceausescu. No analysis of the Party's internal or external policy can be made without taking into consideration his personality. He is the single authority who dictates the Party's internal policies and he is the sole representative of the RCP in its international relations. To such a degree has ceausescu neutralized the institutional role of the Party that it can be fairly asserted that the character of Romania's dissidence against the Soviet Union in the last twenty years is a direct reflection of Ceausescu's personal political behavior. Since his name has become synonymous with that of the Party, Ceausescu represents the key to understanding how Romania has been able to avoid a soviet military intervention in response to its autonomous external policy. Further, it seems normal to focus the analysis upon him since it was his line of foreign policy which created this kind of threat in the first place. Based on these considerations, this chapter will examine ceausescu's ascendancy to absolute power and the significance of his role in avoiding a military confrontation with the Soviet Union. 
In March, 1965, at the age of 47, Nicolae Ceausescu succeeded Gheorghiu-Dej as the leader of the Romanian Workers' Party. He was Gheorghiu-Dej's chosen successor, a choice expressed by the former before his death on March 5, 1965. Even though he had been Secretary of the Central Committee of the Party since 1954, Ceausescu was relatively obscure and unknown. The other two members of the triumvirate of power immediately after Gheorghiu-Dej's death were representatives of the old guard: Chivu Stoica, the President of the State, and Ion Gheorghe Maurer, the Prime Minister.

Eager to establish his authority, Ceausescu launched himself into a dynamic campaign of popularity throughout the country with numerous public appearances and a series of speeches. During the four months that preceded the Ninth RCP Congress held in July 1965, he projected himself as a symbol of a new era in Romania's life, addressing patriotic calls for national unity under the Party's leadership. The Ninth RCP Congress confirmed the new leader of the Romanian ruling team. At the rostrum of the Congress, Ceausescu alone received standing ovations from thousand of delegates and foreign guests, while the other comrades from the Party's highest echelon remained respectfully in the background. At Gheorghiu-Dej's graveside, Ceausescu had eulogized his mentor's memory and promised to keep his policies unchanged. Four months later, Western observers-- 
allowed for the first time to attend a party congress--were surprised that after one minute of silence for Gheorghiu-Dej's memory, the Congress simply forgot the Party's previous leader. It seemed like "he had been in his grave for four decades instead of four months." 1

From the very beginning Ceausescu showed clearly that he was unwilling to share the supreme leadership with anybody else, dead or alive. From 1965 to 1967, preoccupied with the consolidation of his power he continued his campaign across the country with an "image-building" effort deliberately aimed at projecting himself as a young national leader, full of energy and dynamism, endowed with innovative ideas, and sincerely devoted to Romania's development. Consequently, his popularity grew constantly; if in 1966 other party speakers referred to him only occasionally, by mid-1967 almost every Party or government official did so constantly. 2

Although collective leadership remained officially the Party's style of work, Ceausescu's efforts at increasing his personal control over the Party continued constantly. The main battle took place within the standing Presidium which, despite its united front regarding Romanian nationalism and resistance to soviet domination, was nevertheless divided into factions engaged in a struggle for power. These factions were formed by party veterans 
gathered around Chivu Stoica and Gheorghe Apostol, older party intelligentsia centered around Premier Ion Gheorghe Maurer, and the new technocratic generation represented by Nicolae Ceausescu.

To shift the balance of power in his favor, Ceausescu persuaded the Central Committee plenum held in June 1966, to enlarge the Standing Presidium from seven to nine members, promoting in this way two of his close collaborators (Ilie Verdet and Paul Niculescu Mizil) into top party positions. These two political "lieutenants" lost no time in monitoring all levers of power at their disposal to clear the way for Ceausescu's ascendancy. To counteract the spirit of the Gheorghiu-Dej era, a large number of party secretaries were replaced in the provinces and, through successive shufflings, many important officials were removed from state and party positions.

At the National Party Conference held in December 1967, Ceausescu replaced Chivu Stoica as President of the Council of state and thus held both the top position of the Party and that of the state. With Premier Maurer at his side, and two of his rivals from the old guard, Gheorghe Apostol and Emil Bodnaras demoted, Ceausescu's control over the Party appeared to be very strong at the beginning of 1968. The quickness with which Ceausescu strengthened his grip on the party leadership by promoting his men at the expense of older party members arose from two pressing 
reasons: first, to consolidate his own position of power within the Party and, second to deter the Soviet Union's attempts at interference in the Party's internal affairs by using pro-Soviet elements. Since some of the old guard had been trained in the Soviet Union during World War II and had continued to maintain an attitude of loyalty toward the Soviets, Ceausescu perceived their presence in the Party's highest echelon as a direct threat to his personal authority and the Party's autonomy. His suspicions appeared to be confirmed by some evidence that a plot was hatched against his leadership by the Soviet Union, allegedly with the willing collaboration of some top party members belonging to the old guard. ${ }^{5}$ By eliminating these elements from the Party's top positions, Ceausescu prevented Soviet manipulations within the RCP and deprived the USSR of the pretext of "intervention by invitation" to curtail Romania's autonomy.

When the Warsaw Pact troops entered Czechoslovakia in 1968, Ceausescu vehemently condemned the invasion and called on the intervening forces to withdraw from Czechoslovak territory. Speaking to a rally of 100,000 people in Bucharest, he emphasized that "the entire Romanian people will not allow anybody to violate the territory of our homeland." ${ }^{6}$ Whatever Soviet intentions may have been at that time, the Romanian population perceived the danger of Soviet occupation and Ceausescu received the credit for 
saving the country. Using this increased status of popularity and support he continued to concentrate more power in his hands, transforming the collective leadership concept into an empty notion.

At the Tenth RCP Congress held in 1969, Ceausescu's supremacy in the Party leadership was ostensibly displayed: every speaker started and ended his remarks with praises to the "leader." No allusions were made to the era that preceded the Ninth RCP Congress. Socialism, it seemed, had come to Romania only with Ceausescu's leadership. In fact, after the Congress only two members from the Gheorghiu-Dej era remained in the Standing Presidium: Ion Gheorghe Maurer and Emil Bodnaras.

Thus, during Ceausescu's first four years in power the composition of the supreme policy-making party organs became almost entirely committed to him. From that time on he virtually assumed the leadership of every significant Party and state institution: Commander-in-Chief of the Armed Forces (1969), Chairman of the Supreme Council of Economic and Social Development (1973), and President of the Republic (1974). He increased his grip over the Party through its internal ceorganization and the creation of new organs which would facilitate his personal control. For example, the standing Presidium which represented the Party's highest elite, was replaced by the Permanent Bureau in 1974. Depending on the number of relatives or close 
associates promoted by Ceausescu within this elite, the Permanent Bureau has changed its size: starting with five members in 1974, it was enlarged to nine members in 1977 , increased to fifteen in 1979, and reduced again to eight members in 1984. This practice of dispensing great political favors to his numerous family and close associates has led, especially in recent years, to the transformation of Ceausescu's leadership into a "dynastic socialism." The campaign of glorification of Ceausescu's personality and his contribution to every aspect of Romanian life was steadfastly developed during these years. A welldirected propaganda system presented Ceausescu as a Party symbol, a creative interpreter of Marxist-Leninist teachings, a leader who initiated all major events in Romanian society. His daily activity continues to be publicized on the front pages of every newspaper in the country. The evening television news begins usually with videotapes of his current activities. Direct transmissions or videotapes are provided by the television for each of his numerous trips abroad. He is described by the media only in superlative terms: he is "the most brilliant son of the Romanian nation, the leader who crowns a succession of great statesmen of our lineage."

Ceausescu himself feels that his role is a historical necessity. Using Marx's metaphor, 'A violinist 
plays by himself, an orchestra needs a conductor,' he has concluded that the development of modern societies in general, and of socialist societies in particular, needs the existence of "a multilateral conductor with multiple qualities and knowledge." Asserting that in today's society there are many conductors at different levels of social organization, he believes that "all these conductors have to act in a unitary manner, based on a single, central 10 leadership and guidance."

For protecting this central leadership, Ceausescu has surrounded himself with a circle of relatives and close collaborators. For preventing the formation of rival centers of power within the Party, he practices a frequent rotation of cadres. Ceausescu justifies this rotation, which does not include his position, as a remedy against the party's ossification: "we must firmly implement... the rotation of cadres, their appointment from one job to another so as to enrich their experience and enlarge their horizon to strengthen the innovating, revolutionary spirit of the entire Party."

As the chief creator of Romania's dissidence in the last twenty years, Ceausescu has been at the same time its main defender against Soviet military intervention. His defensive policy was based first, on his absolutist leadership which has remained unchallenged in the last twenty years. Through it, Ceausescu was able to eliminate 
any factions and tendencies of opposition within the RCP, thereby presenting the Soviets with a united front of action and with no choices for undermining Romania's external policy from within (the party).

Second, by maintaining a strict domestic orthodoxy he has proved to the Soviets that he has the personal capacity for total control of Romania's society. This control has provided the assurance of his commitment for the emulation of Soviet communism. This fact has undoubtedly contributed to the lessening of the Soviet military threat, enlarging at the same time Ceausescu's freedom in the international arena. Third, Romania's autonomous foreign policy of the last two decades has attracted international attention to Ceausescu's personality. Presenting this policy as an expression of peace and international cooperation, Ceausescu has made it difficult for the Soviets to find an acceptable justification for sanctioning Romania. 
CHAPTER SIX

PARTY IDEOLOGY

Romania's internal policy and its external behavior are directly related to the RCP's ideology. This chapter will examine how this ideology justifies the RCP's leading role in society, and implicitly protects Romania's autonomy against Soviet military intervention.

For the last two decades, ideology in Romania has been unmistakably marked by Ceausescu's philosophy. His personal views about Romanian society and the direction in which it should develop have led to the creation of an ideology which is a mixture between Marxist-Leninist principles interpreted in a personalized view, and ideas of Romanian nationalism. This theoretical amalgan that has come to be known as "Ceausescuism," has been used as the basic doctrine for political education and indoctrination of the general population.

This theory comprises a series of basic coordinates for political education and is centered around Ceausescu's conviction that the historical task of achieving socialism and communism is unconceivable without a communist party that would lead the process of creating a new socialist man. This basic philosophical concept appears clearly in all his speeches dedicated to 
political education. First, the Party: "Our party presents itself... more united than ever and determined to... fulfill its historic mission as [the] leading political force of the Romanian people along the path toward communism." ${ }^{2}$ And again: "Our firm progress is the result of the activity of... all the people, closely united around the party, which is the leading political force of our socialist nation." The purpose of the Party's leading role is "The molding of the new man, the purposeful builder of the social system, [which] is the greatest and most complex task, the loftiest responsibility and the new revolutionary duty of honor of our communist party."

To achieve this complex task the Party has laid constant stress on ideological and political instruction. An example is the ideological program drawn up by the Ideological Commission of the Central Committee of the RCP, "under [the] direct guidance of Comrade Ceausescu." ${ }^{5}$ The program was aimed at increasing the socialist consciousness of the people, raising their level of political knowledge, and popularizing the principles of socialist and communist ethics and equity. This vast instructional program was conceived for a three-year period of study, in the form of seminars, lectures or debates organized once per month for the entire population. For party members and young communists the political training was to be organized within their organizations; for the rest of the 
people the instructional program was supervised by the mass organizations under the Party's guidance.

In order to be adapted to the different levels of knowledge, of the people, the program was structured in stages of complexity, starting with introductory lessons and continuing with more advanced studies. The areas presented or debated in political courses comprised subjects such as: the history of the RCP, the philosophical conception of dialectical and historical materialism, and Marxism as interpreted by Ceausescu's creative thinking. The political-ideological education also became an integral part of curricula in schools and universities and was extended even to preschool children. To facilitate the application of the program, it was established that in each county, town, commune, enterprise and institution political education councils would be created under the leadership of Party organizations.

Since the essence of the ideology is the Party's leading role in all aspects of the society, special attention has been accorded to the manner in which the Party leaders from central and local levels integrate the requirements of the political-educational program into their daily duties. For a close supervision of this aspect, Ceausescu has made frequent visits all over the country during which he has criticized the negative 
attitudes manifested among leading cadres of the Party and state in regard to the application of the program. He has emphasized that in most cases only a small number of individuals, usually those belonging to the councils of political education, were practically involved in political educational work; the majority of the leading cadres, he observed, have been preoccupied with their managerial and technical functions, remaining outside the political process. For Ceausescu, this is not acceptable. In his view, all leading positions no matter in what field of activity, are first political positions. Thus, those who hold these positions are first political leaders and then managers, technical supervisors or other economic or social functionaries. Accordingly, as political leaders their duty is to ensure at their working place a permanent fusion between the political function and all other activities in which they are engaged.

To correct this widespread tendency of separatism, an intensive recycling program was organized for updating the political-educational level of a large number of leading cadres. At the same time the rotation of cadres between administrative positions and party functions, and between central and local levels was increased. It was expected that through these measures the leading cadres could assimilate to a greater degree the necessity of fusion between political and administrative functions, and 
understand better the meaning of the Party's decisions by examining them from a different perspective. Summing up this point of view Ceausescu affirmed that the "Party and state cadres must be good professionals, but at the same time they must be good revolutionaries." A leader, in Ceausescu's concept, cannot merely "be a good engineer, worker, economist or even a good minister;" he should first be "a professional revolutionary."

In conjunction with their higher ideological level and political consciousness, the RCP's leading cadres are expected also to be examples of socialist ethic and morality. Only qualities such as honesty, hard work, patriotism and devotion to the socialization effort can enable them to attain the moral leadership required for inducing into the masses the Party's higher aspirations of creating the new superior man.

However, the requirement for performance and conduct expected from the leading political cadres covers only one area, albeit a major one, of the political-ideological offensive launched by the RCP. Political indoctrination is pursued with great intensity at all levels of society, especially those involving large public audiences. For example, special attention is accorded to artistic and technical intelligentsia, who are considered as major factors in implementing the party's ideological program. 
"Good" literature, for example, could represent an important source of inspiration to the masses for the cultivation of the higher humanistic qualities that characterize the new socialist man. At the same time "correct" movies or playwrights could help the Party's political educational activity by spreading inspirational messages or presenting the RCP's program in a more appealing and emotional expression.

Social and political scientists were called on to emphasize the relationship between the Party and the masses, and stress in their work the historical past of the RCP, its revolutionary struggle and sacrifices that led to the victory of socialism in Romania. It was recommended that their publications and research should enhance the image of the socialist order, raise patriotic feelings among the population, and emphasize the organic ties and continuity between Romania's past and present.

A special role for the transmission of the Party's ideological values was assigned to the technical intelligentsia. Such an emphasis has been determined by the increased development of technical education required by Romania's economic needs. Since it has attracted a large participation, especially youth, technical education has been seen as an effective mechanism for political indoctrination. This task has been carried out by compelling the technical intelligentsia to perform the double role of 
transmitting technical information and ideological messages at the same time. The purpose of this request is to create among the students a perception of unity between "political education and the "real stuff'." 8

The revolutionary character of Marxism, in the Party's view, resides precisely in the fact that it is constantly enriched with the scientific conclusions of social development. It is not a dogma of immutable theses given once and for ever, but a scientific conception. Socialism and communism, Ceausescu asserts, cannot be built "based on a single license, the way they do it in technology." 9 To find the right solutions for every day problems of life, it is necessary that politicians, scientists, and thinkers should together analyze the social development of the country relying on scientific conceptions of Marxism-Leninism and on the ideas of dialectical and historical materialism.

It is this view of a unitary effort carried out under Party leadership which motivates Ceausescu's ideological campaigns all over the country, in which he consistently criticizes retrograde attitudes of sectarianism, technocratism, and bureaucratic stiffness. Theoretical activity, based on Marxist-Leninist conceptions and enriched permanently by the investigation of the realities of contemporary progress, gives the RCP a clear image of society's evolution; it helps the Party to establish a political line of action for every developmental 
stage of building the new system. The leading role of the Party, Ceausescu stresses, is not a goal by itself. The purpose of its work is to create in every socialist collectivity an ideological and moral framework within which people would develop their ability to live and work in a collective spirit and consciously participate in the accomplishment of socialist goals. Speaking about socialist society, Ceausescu emphasizes its organic character: "The society we are building is the society of working people, it relies directly on all its members' creative work." 10 There is a close relationship between the citizens and the society. There are no separate needs between individuals and the collectivity. Consequently, there can be no private sectors or specific activities outside the societal collectivity. Since socialism is the purpose of society, everything inside it should be viewed as a political matter. The attitude of the people must be in conformity with the society's needs; that is, there must be active and conscious participation. No one is allowed to stay outside the working stream or only contemplate the working process.

The party's leading role is a common feature of all communist political systems. Through the party's activity it is expected that socialist practices, methods and attitudes would be implemented and assimilated within the society, while socialist and communist goals would be accepted by the general population. In Ceausescu's ideology 
the masses are expected not only to accept the new system but to participate consciously in building it. Ceausescu expects from all people a total adherence to the socialist system and does not accept the thesis that consciousness has a tendency of lagging behind material life:

The deficiencies existing in the ideological, political and cultural-educative activity, the negative phenomena emerging in social life, in the behavior of some people can be often explained by the thesis about consciousness lagging behind the development of material 1ife. To accept such a justification of our drawbacks means to encourage a passive, defeatist attitude with profoundly negative consequences on society's development. 11

To think correctly is not enough, the people must also act correctly to implement the Party's policy. A "correct" action is emphasized as opposed to a participation motivated by spontaneous impulses. Mass spontaneity is not supported by the Party; it leads only to satisfaction of immediate demands losing sight of the cardinal goals of the revolutionary movement.

In Ceausescu's ideology the people's participation should take the form of a high degree of mobilization under the Party's guidance because the Party is better equipped than the masses to follow correctly the "inevitable road" already revealed by Marxist-Leninist teaching. This is then, the core of Ceausescu's ideology which motivates the necessity of the Party's leadership in society. His argument is presented not as a personal desire but as a logical succession of phases imposed by historical 
necessity. Basically he maintains that socialism and communism are the highest forms of human society. If socialism is what society needs then its citizens, who form it, could not but have the same needs. Based on these integrally related needs and interests there can be no other direction of development but socialism. As the political goal of society, its print is marked on everything in the society. Political aspects cannot be separated from other activities, nor ignored. They are blended at every social level with other factors, even though many people do not realize that.

To achieve socialist and communist goals, a total mobilization of human and natural resources is needed. This mobilization cannot be accomplished by mass spontaneity, which has the tendency only of achieving immediate goals that provide instant satisfaction. This practice will dilute the effort and delay the advancement toward the major goals which will offer greater satisfactions with lasting effects for all citizens. To stay on the right track a vanguard is needed to lead the masses; this is the place filled by the Party. Its leading role is justified by its higher political consciousness and ideological education, which enables its members to understand the historical path of societal development. Its existence is demanded by the historical evolution of society; its legitimacy is the political character of society. It is acting in accordance with society's interests, thus implicitly serving its 
citizens. If its role is not understood yet by all citizens it is because of the lack of their political education. The higher the political education of the masses the greater will be the chances for society to reach its socialist and communist goals. From this derives the necessity of a permanent political-educational program that will result in the creation of a new man with higher humanistic qualities suitable for the future society.

Emphasizing the higher importance of ideological educational activity, Ceausescu concludes: "There is no exaggeration in saying that the very communist future of our homeland depends on the successful development of this work."

It appears obvious from this presentation that the RCP's ideology, molded by Ceausescu's personalized thinking, totally justifies the Party's leading role in Romania. And this is the basic idea that was underlined throughout this study. What other proof of communist loyalty can the Soviets possibly ask for, other than those offered by the RCP's domestic policy? For the last twenty years no other Soviet satellite in Eastern Europe has preserved internal communist orthodoxy so rigorously and in so rigid a manner. Ceausescu's ideology, which is nothing more then a theoretical device for enforcing this orthodoxy, thus represents the Party's best defense against Soviet suspicions created by Romania's external behavior. And as 
events have demonstrated until now, this "ill-behavior" has been always counteracted by a "healthy" domestic policy. It seems that Ceausescu's unabated commitment to his historical mission of building socialism and communism on Romanian soil, and his obsessive vision of creating the new socialist man, have weighed more in Soviet eyes than his international rhetoric or misconduct. 
PART III

\section{CONCLUSIONS}

Romania's dissidence within the Soviet bloc is a complex phenomenon determined during the last two decades by interrelated factors of an historical, economical, social and political nature. From this complex phenomenon, this study has separated for examination only one aspect, namely Soviet tolerance of Romania's dissidence.

This analysis has focused upon the role played in this process by the RCP during 1965-1985 period. The result of this analysis has confirmed this study's hypothesis that Romania's tight internal policy has represented one of the major reasons for Soviet tolerance of the former's independent foreign policy. The study has shown that in the last two decades the RCP has maintained a total and undisputed internal control, which has led foreign observers to label Romania as the most tightly orthodox communist state in Eastern Europe. This internal orthodoxy can be summarized in the following conclusions:

1. During the 1965-1985 period, the RCP constantly enlarged its representative character by increasing its membership and extending its organizational and territorial coverage. 
The party also consolidated its structural unity and hierarch and totally subordinated state and mass organizations to its leadership. Emphasizing its status as a mass organization and its firm internal control over society, the Party sent to the Soviets a clear message assuring them of Romania's internal stability, but also stressing same time its unabated commitment to the preservation of the country's sovereignty.

2. The Party's domestic policy was characterized by the repression of human rights and democratic liberties. This fact was illustrated by the crushing of the intellectual and religious dissident movement for human rights, the harsh repression of the miners' strike in the Jiu Valley in 1977, the rigid control and censorship imposed upon Romania's cultural life, and the opposition to emigration. 3. For almost twenty years the RCP has been ruled by the absolutist leadership of Nicolae Ceausescu. Following a few years of struggle for power in the mid-1960s, during which he removed from the Party's top positions any potential rivals belonging to the old guard, he consolidated his position as the head of both the party and the state. Surrounded by an elite of relatives and close associates who protect his absolute power, Ceausescu has engaged in a non-stop campaign of glorification comparable in size and intensity with Stalin's cult of personality. He has used Romania's dissidence in the international sphere as a 
springboard for achieving his ambitions of political power and international recognition.

4. Romania's internal orthodoxy has found its justification in the Party's ideology. The RCP's ideology, representing a blend of Marxist-Leninist principles and Ceausescu's philosophical concepts, emphasizes the necessity of the Party's leading role in society as the only way of achieving the historical task of socialism: the creation of a new man. Since this long and complex historical process requires a high level of socialist consciousness, the Party set up a permanent program of indoctrination that practically includes the entire population of the country. Through this program the RCP intends to raise the political and ideological level of the population so that they have a better understanding of the party's political role and policy.

Romania's dissidence had its origin in a genuine national desire for de-Russification and independence. These popular aspirations were used by the RCP as the basis for legitimacy and power, but were altered in time by Ceausescu's personal ambitions. During the last two decades Romania has indeed been the Soviet Union's most dissident ally but at the same time its most devoted follower in domestic policy. The RCP's desire was not to break with the Socialist camp but to consolidate within it a regime of national communism less dependent on the Soviet Union. Since Romania's socialist status and its integration in the 
East European model were never challenged during this process, it is understandable that the country's autonomous foreign policy was framed by limitations and restrictions. It can be said that these limitations which Romania has learned to recognize and respect over the years, together with its self-proclamation in the international arena as a country committed to peace and international cooperation, have contributed to some degree to the avoidance of Soviet military sanctions against it. However, based on this study's research and analysis and the consideration of opinions expressed by numerous scholars who have studied Romania's case, it is this study's conclusion that Romania's internal orthodoxy has been the major reason that has prevented soviet military intervention. The internal orthodoxy, closely resembling the main features of Soviet society, represented the guarantee of communist loyalty presented to the Soviets by the RCP in exchange for Romania's external behavior. 
FOOTNOTES

Introduction

1. David Floyd, Romania: Russia's Dissident Ally, (New York: Praeger, 1965); R.V. Burks, "The Romanian National Deviation: An Accounting," in Eastern Europe in Transition, ed. $\mathrm{K}$. London (Baltimore: The John Hopkins University Press, 1966), pp. 93-113.

2. Paul Lendvai, Eagles in Cobwebs, (New York: Doubleday Co., Inc. 1969), pp. 328-329.

3. Scinteia, (Bucharest), 26 April 1964.

4. Stephen Fischer-Galati, The Socialist Republic of Romania, (Baltimore: The John Hopkins University Press, 1969), p. 76.

5. Stephen Fischer-Galati, argues that the term "independence" or "independent course" have never been used in Romania or by Romanians. He considers that a more proper designation of the process should be "Romanian road to socialism." See e.g., his article "Romania's Independent Course: Retrospect and Prospects, "in International Review (September-October 1984): 9 .

Chapter One

1. Harry Schwartz, Eastern Europe in the Soviet Shadow, 
(New York: The New York Times Co., 1973) p. 22.

2. Stephen Fischer-Galati, The Socialist Republic of Romania, (Baltimore: The John Hopkins University Press, 1969), p. 40.

3. Donna Bahry and Cal Clark, "Political Conformity and Economic Dependence in East Europe: The Impact of Trade with the West," in The Foreign Policies of East Europe, ed. Ronald H. Linden (New York: Praeger, 1980), p. 145 Table 5.1.

Chapter Two

1. Charles Gati, "The Forgotten Region," Foreign Policy 19 (Summer 1975): 135.

2. Ibid. p. 144 .

3. Idem, "Soviet Empire: Alive But Not Well", Problems of Communism 34 (March-April 1985): 73 .

4. Ibid. p. 80 .

5. Ibid. p. 81 .

6. Ibid. p. 84 .

7. Ibid. p. 86 .

8. Roger E. Kanet, "Research on East European Foreign Policy: Other Needs, Other Areas, New Directions," in The Foreign Policies of East Europe, Ed. Ronald H. Linden (New York: Praeger, 1980), p. 311.

9. Ibid.

10. Ibid. 
11. Ibid. p. 312 .

12. Ibid. p. 314

13. Ibid. p. 316

14. Ibid.

15. Ladis K. D. Kristof, "The Case of Romania," Studies in Comparative Communism 4 (April 1971): 37.

16. Ibid. p. 39.

17. Ibid. p. 42.

18. Vernon V. Aspaturian, Comment to Barbara Jancar's article "Eastern Europe: Toward a New Paradigm," Studies in Comparative Communism 8 (Autumn 1975): 301 .

19. Ibid. p. 303.

20. Gordon Skilling, "The Crisis in Eastern Europe Communism: National and International," International Journal 39 (Spring 1984): 455.

21. Andrzej Korbonski, "East Europe: Soviet Asset or Burden? The Political Dimension," in The Foreign Policies of East Europe, ed. Linden, p. 301.

22. Ibid. p. 302 .

23. Ibid.

24. Ibi.d. p. 304

25. Ibid. p. 306 .

26. Peter Summerscale, The East European Predicament, (New York: St. Martin's Press, 1982), p. 46.

27. Ibid. p. 47.

28. Ibid. p. 48. 
29. Ibid. p. 51 .

30. Ibid. p. 91 .

31. Ibid.

32. Robert L. Farlow, "Romania: The Politics of Autonomy," Current History 74 (Apri1 1978): 168.

33. Ibid.

34. Ibid.

35. Ibid. p. 169

36. Ibid. P. 186.

37. George Schopflin, "Romanian Nationalism," Survey 20 (Spring-Summer 1974): 93.

38. Ibid. p. 103.

39. Ibid.

40. Ibid. P. 104 .

41. Ibid.

42. Vladimir Tismaneanu, "Ceausescu's Socialism," Problems of Communism 34 (January-February 1985): 50.

43. Cal Clark, "Balkan Communist Foreign Policy: A Linkage Perspective," in The Foreign Policies of East Europe, ed. Linden, p. 23.

44. Ibid. p. 24 .

45. Ibid.

46. Stephen Fischer-Galati, "Romania's Development as a Communist state," in Romania in the 1980s, ed. Daniel N. Nelson (Boulder, Colorado: Westview Press, 1981), p. 4.

47. Ibid. p. 5 
48. Ibid. p. 7 .

49. Lawrence S. Graham, Romania a Developing Socialist State, (Boulder, Colorado: Westview Press, 1982), p. 61.

50. Ibid. p. 121 .

51. Ibid. p. 123.

52. Ibid.

53. Trond Gilberg, "Romania's Growing Difficulties," Current History 83 (November 1984): 375.

54. Ibid.

55. Ibid.

56. Ibid. p. 376 .

57. Ibid.

58. Ibid.

59. Ibid. p. 379.

60. Ibid.

61. Ibid. p. 390.

62. Ibid.

63. Ibid. p. 391.

64. Ibid.

65. Robert L. Farlow, "Romanian Foreign Policy: A Case of Partial Alignment," Problems of Communism 20 (November-December 1971): 55 .

66. Ibid. p. 63 .

67. Ibid.

68. Ibid. 
69. Ibid.

70. Christopher D. Jones, "The Soviet Hegemony in Eastern Europe: The Dynamics of Political Autonomy and Military Intervention," World Politics 29 (January 1977): 216 .

71. Ibid. p. 231.

72. Ibid. p. 234 .

73. Ibid.

74. Graeme J. Gill, "Romania: Background to Autonomy," Survey 21 (Summer 1975): 108.

75. Ibid.

76. Ibid. p. 111.

77. Ibid.

78. Ibid.

79. Ibid.

80. Ibid. p. 113.

81. Robert R. King, "The Problems of Romanian Foreign Policy," Survey 20 (Spring-Summer 1974): 105.

82. Ibid. P. 108.

83. Ibid. p. 120 .

84. Ronald H. Linden, "Romanian Foreign Policy in the $1980 \mathrm{~s}, "$ in Romania in the 1980s, ed. Nelson, p. 234. 85. Ibid. p. 239.

86. Stephen Fischer-Galati, "Romania's Independent Course," International Review (September-October 1984): 12. 
Chapter Three

1. Washington Post, 23 May 1977, sec. A. p. 19. col. 1.

"Romania Crushes Intellectuals' Dissent."

2. Ibid.

3. Ibid.

4. Ibid.

5. General Survey, Romania (Romania: I. P. Galati, 1982), p. 24 .

6. Chicago Tribune, 6 september 1977, sec. 3. p. 02. col. i.

7. Washington Post, 27 November 1977, sec. A. p. 01. col. 5. "Labor Strife in Romania."

8. Ibid.

9. "Nicolate Ceausescu's vist to mining area," Foreign Broadcast Information Service-Eastern Europe (FBIS-EEU), 9 November 1977, P. H3.

10. Washington Post, 27 November 1977.

11. Chicago Tribune, 14 January 1979, sec. 2 p. 04 col 5L.

12. Washington Post, 27 November 1977.

13. Gail W. Lapidus, "Literature and the Arts," in Totalitarian Dictatorship and Autocracy, ed. Carl J. Friedrich and zbigniew K. Brzezinski (New York: Frederick A. Praeger, Inc., Publishers, 1966), p. 338. 14. Ibid. p. 331 .

15. Nicolae Ceausescu, "Report at the Twelfth RCP Congress," in Romania: Documents-Events (Bucharest: 
News Agency, 1979), p. 97.

16. "Cultural-Ideological Program approved by the Executive Political Committee of the RCP Central Committee on 14 September 1976," FBIS-EEU, 18 October 1976, pp. H14-H 15.

17. Lapidus, Totalitarian Dictatorship, p. 331.

18. Ceausescu, "Address at the RCP Central Committee plenary session on 29 June 1977," FBIS-EEU, 11 July 1977, p. HII.

19. Trond Gilberg, "Romania's Growing Difficulties," Current History 83 (November 1984): 376.

20. "Cultural Ideological Program," 1976, p. H22.

21. Ibid.

22. Ceausescu, "Speech at the Working Meeting on Organizational and Political Educational Activities," FBIS-EEU, 9 August 1983, p. H10.

23. Ceausescu, "Report at the Twelfth RCP Congress," 1979, p. 99.

24. Ibid. p. 74 .

25. Gilberg, "Modernization, Human Rights, Nationalism: The Case of Romania," in The Politics of Ethnicity in Eastern Europe, ed. George Klein and Milan J. Reban (New York: Columbia University Press, East Eruopean Monographs, 1981), p. 202.

26. Ceausescu, Procese si Tendinte Fundamentale ale Dezvoltarii Mondiale Contemporane, (Bucuresti: Editura 
Politica, 1979), p. 124.

27. Ibid.

28. Ibid.

29. Robert Maxwell, Nicolae Ceausescu, Builder of Modern Romania and International Statesman (Oxford: Pergamon Press, 1983), p. Aix.

Chapter Four

1. Nicolae Ceausescu, Raport la cel de-al 9-lea Congres al Partidului Comunist Roman (Bucuresti: Editura Meridiane, 1965), p. 73.

2. Ceausescu, "Report at the Eleventh RCP Congress," 1974, FBIS-EEU, 27 November 1974, p. H37.

3. Ceausescu, "Report at the Twelfth RCP Congress" 1979, Romania: Documents-Events (Bucharest: The Romanian News Agency, 1979), p. 76.

4. "Political-Organizational Activity Carried out in 1984 by the Party Committees and Organizations to Implement the Party Decisions and Directives," FBIS-EEU, 9 April 1985, p. H9.

5. Ibid.

6. Ceausescu, "Report at the Twelfth RCP Congress," 1979 p. 83.

7. "Political-Organization Activity Carried out in 1984," FBIS-EEU, 9 April 1985, p. H9.

8. Ceausescu, "Report at the Twelfth RCP Congress," 1979, p. 82 . 
9. Ibid. p. 75 .

10. Ceausescu, "Speech at the Working Meeting on

Organizational and Political Educational Activities," FBIS-EEU, 9 August 1983, p. H5.

11. Ceausescu, "Report at the Twelfth RCP Congress," 1979, p. 81 .

12. Ibid. p. 82 .

13. Aurel Braun, Romanian Foreign Policy Since 1965 (New York: Praeger Inc., Publishers, 1978),p. 20.

14. Ceausescu, "Report at the Eleventh RCP Congress," 1974, p. H39.

15. Ibid.

16. Lawrence S. Graham, Romania a Developing Socialist State, (Boulder, Colorado: Westview Press, 1982), p. 62.

17. Ibid. p. 66 .

18. Ceausescu, "Report at the Twelfth RCP Congress," 1979, p. 87.

19. Daniel N. Nelson, "Workers in a Workers" State," in Romania in the 1980s, ed. Daniel N. Nelson (Boulder, Colorado: Westview Press, 1981), p. 187. 20. Ibid. p. 188 .

Chapter Five

1. Paul Lendvai, Eagles in Cobwebs, (New York: Doubleday Col, Inc. 1969), p. 291.

2. Mary Ellen Fischer, "Idol or leader? The origins and 
future of the Ceausescu cult," in Romania in the 1980s, ed. Daniel N. Nelson (Boulder, Colorado: Westview Press, 1981), p. 122.

3. Lendvai, Eagles in Cobwebs, p. 398.

4. Ibid. p. 399.

5. Aurel Braun, Romanian Foreign Policy Since 1965 (New York: Praeger Inc., Publishers, 1978), p. 18.

6. Fischer, "Idol or leader?" p. 124.

7. Ion Gheroghe Maurer resigned for "reason of health" in 1974; Emil Bodnaras died in 1976.

8. Fischer, "Idol or leader?, p. 131.

The idolizing campaign reaches its climax each year on January 26 when the Party and the State celebrate Ceausescu's birthday; see e.g. FBIS-EEU, 27 January 1984, p. HI-3, and FBIS-EEU, 30 January 1985, p. H4-7.

9. Robert Maxwell, Nicolae Ceausescu, Builder of Modern Romania and International Statesman (Oxford: Pergamon Press, 1983), p. 74 .

10. Ibid.

11. Nicolae Ceausescu, "Report at the Twelfth RCP Congress," in Romania: Documents-Events (Bucharest: The Romanian News Agency, 1979), p. 83.

Chapter Six

1. Trond Gilberg, "Political Socialization in Romania: Prospects and Performance," in Romania in the 1980s: ed. Daniel N. Nelson (Boulder, Colorado: Westview 
Press, 1981), p. 148.

2. Nicolae Ceausescu, "Report at the Eleventh RCP Congress," 1974, FBIS-EEU, 27 November 1974, p. H37.

3. Ceausescu, "Report at the Thirteenth RCP Congress," 1984, FBIS-EEU, 20 November 1984, P. H5.

4. Robert Maxwell, Nicolae Ceausescu, Builder of Modern Romania and International Statesman (Oxford: Pergamon Press, 1983), p. 113.

5. "Cultural-Ideological Program approved by the Executive Political Committee of the RCP Central Committee on 14 September 1976," FBIS-EEU, 18 October 1976, p. H5.

6. Ceausescu, "Speech at the Working Meeting on Organizational and Political Educational Activities," FBIS-EEU, 9 August 1983, pp. H7-8.

7. Gilberg, "Political Socialization in Romania," Romania in the 1980s, pp. 154-155.

8. Ibid. p. 157 .

9. Maxwel1, Ceausescu Builder of Modern Romania, p. 115.

10. Ibid. p. 117.

11. Ibid. p. 116.

12. Ibid. p. 117. 
BIBLIOGRAPHY

A. Books

1. Braun, Aurel. Romanian Foreign Policy Since 1965. New York: Praeger Inc., Publishers, 1978.

2. Ceausescu, Nicolae. Procese si Tendinte Fundamentale ale Dezvoltarii Mondiale Contemporane. Bucuresti: Editura Politica, 1979.

3. Floyd, David. Romania: Russia's Dissident Ally. New York: Praeger, 1965.

4. Galati, Fischer Stephen. The Socialist Republic of Romania. Baltimore: The John Hopkins University Press, 1969.

5. General Survey, Romania. Romania: I.P. Galati, 1982.

6. Graham, S. Lawrence. Romania a Developing Socialist State. Boulder, Colorado: Westview Press, 1982.

7. Lendvai, Paul. Eagles in Cobwebs. New York: Doubleday Co. Inc. 1969.

8. Maxwe11, Robert. Nicolae Ceausescu, Builder of Modern Romania and International Statesman. Oxford: Pergamon Press, 1983.

9. Schwartz, Harry. Eastern Europe in the Soviet Shadow. New York: The New York Times Co., 1973.

10. Summerscale, Peter. The East European Predicament. New York: St. Martin's Press, 1982. 
B. Articles, Periodicals and Brochures.

1. Aspaturian, V. Vernon. Comment to Barbara Jancar's article "Eastern Europe: Toward a New Paradigm." Studies in Comparative Communism 8 (Autumn 1975).

2. Bahry, Donna and Clark Cal. "Political Conformity and Economic Dependence in East Europe: The Impact of Trade with the West." In The Foreign Policies of East Europe. Ed. Ronald H. Linden. New York: Praeger, 1980 .

3. Burks, R. V. "The Romanian National Deviation: An Accounting." In Eastern Europe in Transition. Ed. K. London. Baltimore: The John Hopkins University Press, 1966.

4. Ceausescu, Nicolae. Raport la cel de-al 9-lea Congres al Partidului Comunist Roman. Bucuresti: Editura Meridiane, 1965.

5. "Report at the Eleventh RCP Congress." In Foreign Broadcast Information Service - Eastern Europe (FBIS-EEU). 27 November 1974.

6. -1..... "Report at the Twelfth RCP Congress." In Romania: Documents-Events. Bucharest: The Romanian News Agency, 1979.

7. - "Report at the Thirteenth RCP Congress." In FBIS-EEU. 20 November 1984.

8. - "Speech at the Working Meeting on Organizational and Political Educational Activities." In FBIS-EEU. 9 August 1983. 
9. -...... "Address at the RCP Central Committee Plenary Session on 29 June 1977." In FBIS-EEU. 11 July 1977.

10. -..... "Visit to mining area." In FBIS-EEU. 9 November 1977.

11. Chicago Tribune. 6 September 1977. Sec. 3. p. 02. col. 1.; 14 January 1979. Sec. 2. p. 04. col. 1. $5 \mathrm{~L}$.

12. "Cultural-Ideological Program approved by the Executive Political Committee of the RCP Central Committee on September 14 1976." In FBIS-EEU. 18 October 1976.

13. Farlow, R. Robert. "Romania: The Politics of Autonomy." Current History 74 (April 1978).

14. -..-. "Romanian Foreign Policy: A Case of Partial Alignment." Problems of Communism 20 (NovemberDecember 1971).

15. Fischer, Mary Ellen. "Idol or leader? The origins and future of the Ceausescu cult." In Romania in the 1980s. Ed. Daniel N. Nelson. Boulder, Colorado: Westview Press, 1981.

16. Galati, Fischer Stephen. "Romania's Development as a Communist state." In Romania in the 1980s, 1981.

17. -...... "Romania's Independent Course: Retrospect and Prospects." International Review (SeptemberOctober 1984).

18. Gati, Charles. "The Forgotten Region." Foreign Policy 19 (Summer 1975). 
19. - "Soviet Empire: Alive but not well." Problems of Communism 34 (March-April 1985).

20. Gilberg, Trond. "Romania's Growing Difficulties." Current History 83 (November 1984).

21. - Modernization, Human Rights, Nationalism: The Case of Romania." In The Politics of Ethnicity in Eastern Europe. Ed. George Klein and Milan J. Reban. New York: Columbia University Press, East European Monographs, 1981.

22. - Political Socialization in Romania: Prospects and Performance." In Romania in the 1980s, 1981.

23. Gill, J. Graeme. "Romania: Background to Autonomy." Survey 21 (Summer 1975).

24. Jones, D. Christopher. "The Soviet Hegemony in Eastern Europe: The Dynamics of Political Autonomy and Military Intervention." World Politics 29 (January 1977).

25. Kanet, E. Roger. "Research on East European Foreign Policy: Other Needs, Other Areas, New Directions." In The Foreign Policies of East Europe, 1980.

26. King, R. Robert. "The Problems of Romanian Foreign Policy." Survey 20 (Spring-Summer 1974).

27. Korbonski, Andrzej. "East Eruope: Soviet Asset or Burden? The Political Dimension." In The Foreign Policies of East Europe, 1980. 
28. Kristof, K. D. Ladis. "The Case of Romania." Studies in Comparative Communism 4 (Apri1 1971).

29. "Labor Strife in Romania." Washington Post, 27 November 1977, Sec. A. p. 01. col. 5.

30. Lapidus, W. Gail. "Literature and the Arts." In Totalitarian Dictatorship and Autocracy. Ed. Carl J. Friedrich and zbigniew K. Brzezinski. New York: Frederick A. Praeger, Inc., Publishers, 1966.

31. Linden, H. Ronald. "Romanian Foreign Policy in the 1980s." In Romania in the 1980s, 1981.

32. Nelson, N. Daniel. "Workers in a Workers' State." In Romania in the 1980s, 1981.

33. "Political-Organizational Activity Carried Out in 1984 by the Party Committees and Organizations to Implement the Party Decisions and Directives." FBIS-EEU. 9 April 1985.

34. "Romania Crushes Intellectuals" Dissent." Washington Post, 23 May 1977. Sec. A. P. 19. col. 1.

35. Schopflin, George. "Romanian Nationalism." Survey 20 (Spring-Summer 1974).

36. Scinteia. Bucuresti, 26 Aprilie 1964.

37. Skilling, Gordon. "The Crisis in Eastern Europe Communism: National and International." International Journal 39 (Spring 1984).

38. Tismaneanu, Vladimir. "Ceausescu's Socialism." Problems of Communism 34 (January-February 1985). 
VITA

Title of Thesis:

DISSIDENCE WITHIN THE SOVIET BLOC:

THE CASE OF ROMANIA

Name: Emil Craciun

Born: November 11, 1939, Romania

Married, U. S. Resident

Education: 1947-1953 Elementary School, Romania

1953-1956 High School, Romania

1958-1963 University of Bucharest, Romania College of Geography and Geology. Graduated in 1963, with a degree of Masters of Arts in Geography and Biology.

Employment: 1964-1977 National Institute of Hydrology and Meterology of Romania-SW Branch Position: Head of the Research and Information Department for Hydrological data; Romania Representative in the RomanianYugoslav Hydrological Commission of Borders Waters.

1963-1964 High School teacher: Geography, Geology, Biology.

Related Trave1: Bulgaria, Czechoslovakia, Hungary, Poland and Yugoslavia.

Arrived in the United States in september 1977 for family reunification.

Major Department: International studies 